\title{
Inhibitor of apoptosis, IAP, genes play a critical role in the survival of HIV- infected macrophages
}

\begin{abstract}
Ramon Edwin Caballero ${ }^{*}, 1,2$, Simon Dong ${ }^{*}$, , Niranjala Gajanayaka $^{*}$, , Hamza Ali $^{1}$, Edana Cassol $^{3}$, William D Cameron ${ }^{1,4}$, Robert Korneluk ${ }^{1,2}$, Michel J. Tremblay, ${ }^{5}$ Jonathan Angel ${ }^{1,4}$, Ashok Kumar 1,2,6

${ }^{1 *}$ Department of Biochemistry, Microbiology, and Immunology, Faculty of Medicine, University of Ottawa, ${ }^{2}$ Apoptosis Research Centre, Children's Hospital of Eastern Ontario Research Institute, Ottawa, ${ }^{3}$ Department of Health Sciences, Carleton University, Ottawa, Canada; ${ }^{4}$ Division of Infectious Diseases, The Ottawa Hospital, and the Ottawa Hospital Research Institute, Ottawa, Ontario, Canada ${ }^{5}$ Axe des Maladies Infectieuses et Immunitaires, Centre de Recherche du Centre Hospitalier Universitaire de Québec-Université Laval, and Département de microbiologie et immunologie, Faculté de médecine, Université Laval, Québec, Canada; ${ }^{6}$ Department of Pathology and Laboratory Medicine, Faculty of Medicine, University of Ottawa, Ottawa, ON, Canada
\end{abstract}

Running Title: IAPs protect HIV-infected macrophages

*These authors contributed equally to this work.

Address correspondence to: Ashok Kumar, Division of Virology, Research Institute, Children’s Hospital of Eastern Ontario, University of Ottawa, 401 Smyth Road, Ottawa, Ontario, Canada, K1H 8L1. Phone: 613-737-7600 ext 3920. E-mail address: akumar@uottawa.ca 


\section{Summary}

After more than 30 years of rigorous and intensive research since the identification of HIV-1, much progress has been made in understanding and controlling the pathogenesis of the virus. However, successful cure is currently unavailable. HIV-1 can remain undetected in various cell types, including memory $\mathrm{T}$ cells and macrophages, which make it difficult to achieve viral clearance without inciting cell death in infected cells. The "shock and kill” approach aims to reawaken dormant integrated virus and boosts host's immune system for viral clearance in latently infected CD4+ T cells. However, to completely eradicate HIV in infected individuals, it is imperative to eliminate both CD4+ T cells and myeloid tissue reservoirs. Here we show that inhibition of the inhibitor of apoptosis (IAP) pathway, a cellular signalling pathway responsible for controlling cell death, by IAP inhibitors, smac mimetics can be utilized to kill HIV-infected macrophages. Deletion of cellular IAP proteins using smac mimetic, a synthetic anti-cancer compound currently being tested in several clinical trials, rendered HIV-infected macrophages susceptible to cell death. Herein, our results suggest that modulation of the IAP-associated signaling pathways may be a potential strategy for selective killing of HIV-infected macrophages. 


\section{Abstract:}

Latent viral reservoirs of HIV-1 that persist despite antiretroviral therapy (ART) are major barriers for a successful cure. Macrophages serve as viral reservoirs due to their resistance to apoptosis and HIV-cytopathic effects. We have previously shown that inhibitor of apoptosis proteins (IAPs) confer resistance to HIV-Vpr-induced apoptosis in normal macrophages. Herein, we show that second mitochondrial activator of caspases (SMAC)-mimetics (SM) specifically induce apoptosis of monocyte-derived macrophages (MDMs) infected in vitro with a R5-tropic laboratory strain expressing heat stable antigen, and GFP-expressing HIV, chronically infected U1 cells, and ex-vivo derived MDMs from naïve and ART-treated HIV patients. SM-induced cell death was found to be mediated by IAPs using IAP siRNAs, was independent of endogenously produced TNFa and was attributed to the concomitant downregulation of IAP-1/2 and the receptor interacting protein kinase-1 degradation following HIV infection. Altogether, modulation of the IAP pathways may be a potential strategy for selective killing of HIV-infected macrophages in vivo. 


\section{Introduction}

Macrophages $(\mathrm{M} \phi)$ are permissive to productive infection with HIV and a source of viral progeny for transmission to other cell types such as T cells [1-7]. HIV-infected M $\phi$ are widely distributed in tissues such as gastrointestinal and other mucosal tissues, lymph nodes and within the central nervous system where they have a life span extending from months to years [8-13]. In contrast to the characteristic depletion of CD4+ $\mathrm{T}$ cells, $\mathrm{M} \phi$ do not decline in number, are resistant to apoptosis, survive active viral replication, and harbor unintegrated and integrated viral DNA in a state of latency $[1,2,14-23]$. In patients on effective antiretroviral therapy (ART), $\mathrm{M} \phi$ serve as reservoirs as HIV persists in these cells, shielded against various host anti-viral responses and respond poorly to ART [1-3,15,24]. Moreover, infected $\mathrm{M} \phi$ accumulate and retain virions within unique compartments designated as virus-containing compartments (VCCs) $[25,26]$. The virions present in VCC are protected from neutralizing antibodies and are inaccessible to anti-viral drugs [27-29]. Since HIV-infected $\mathrm{M} \phi$ are not cleared by CD8 ${ }^{+} \mathrm{T}$ cells, neither current ART nor the immune system is able to effectively eliminate this reservoir [24].

While several recent studies support that M $\phi$ serve as a major non-T cell HIV reservoir [30-38], the role of M $\phi$ in HIV infection and persistence has been conclusively demonstrated by employing humanized BLT and myeloid only mice (MoM mice containing myeloid cells devoid of $\mathrm{T}$ cells). Honeycutt et al show that replication competent virus could be recovered from tissue $\mathrm{M} \phi$, and the transfer of infected $\mathrm{M} \phi$ into uninfected animals resulted in sustained infection demonstrating that $\mathrm{M} \phi$ are genuine targets for HIV infection in vivo [3]. Further, they demonstrated that HIV persists in M $\phi$ following suppressive ART in vivo in MoM model [39]. 
Therefore, to completely eradicate HIV in individuals on ART, it is imperative to eliminate both CD4+ T cells and myeloid tissue reservoirs. Most research to date has focused on eliminating the latent reservoir of CD4+ $\mathrm{T}$ cells by employing strategies to reactivate $\mathrm{HIV}$ in $\mathrm{T}$ cells and elimination of reactivated HIV-infected cells by host immunity [40-42]. However, approaches towards killing of HIV-infected $\mathrm{M} \phi$ in vitro or in vivo are not well studied. Two recent studies have attempted to clear $\mathrm{M} \phi$ reservoir by targeting infected $\mathrm{M} \phi$ with CSF-1 receptor antagonists [43] and galactin-3 [44] with some success.

In order to devise strategies to eliminate HIV-infected $\mathrm{M} \phi$, it is imperative to identify apoptosis-related genes and signaling proteins involved in resistance of HIV-infected $\mathrm{M} \phi$ to apoptosis. The mechanism underlying resistance of infected $\mathrm{M} \phi$ to HIV-induced apoptosis may relate to the differential expression of pro- and anti-apoptotic genes including inhibitors of apoptosis (IAP) proteins $[15,45]$. The role of IAPs has been studied by employing antagonists of second mitochondria-derived activator of caspases (Smac), Smac mimetics (SM). SMs are small peptides that competitively inhibit Smac-IAP-1/2 interactions and repress anti-apoptotic functions of IAP proteins. Recently, IAP1/2 and survivin, another member of the IAP family were suggested to be involved in survival of HIV-infected CD4+ T cells [46,47]. In addition, IAPs have been implicated in protection against hepatitis B infection and in the reversal of HIV latency in CD4+ T cells $[48,49]$. Using HIV-Vpr as an apoptosis-inducing agent, we have shown a protective role for IAP genes in resistance to cell death in $\mathrm{M} \phi$ [50-52]. CpG-induced protection against apoptosis and mitochondrial depolarization in monocytic cells was shown to be mediated by c-IAP-2 induction [50,52]. Moreover, down regulation of IAP-1/2, by using siRNAs and SMs, sensitized M $\phi$ to Vpr-induced apoptosis [51]. Therefore, strategies based on suppressing IAPs by 
bioRxiv preprint doi: https://doi.org/10.1101/543017; this version posted February 6,2019 . The copyright holder for this preprint (which was not certified by peer review) is the author/funder, who has granted bioRxiv a license to display the preprint in perpetuity. It is made available under aCC-BY 4.0 International license.

employing SMs, may be useful in killing HIV-infected M $\phi$. Herein, we show that SMs induced apoptosis in in vitro HIV-infected $\mathrm{M} \phi$ and that this may occur through the concomitant down regulation of both IAPs and receptor interacting protein kinase-1 (RIPK-1). 


\section{Results}

SMs induce cell death in HIV-infected myeloid U1 cells but not in counterpart uninfected U937 cells

SMs bind to cIAP1/2 and promote their E3 ligase activity which leads to their autoubiquitination, subsequent proteasome degradation and apoptosis [53,54]. We have previously shown that cIAP1/2 genes play a protective role in mediating survival of M $\phi$ in response to Vprinduced cell death [50-52]. To determine whether SMs impact apoptosis in HIV-infected M $\phi$, chronically infected U1 cells and uninfected counterpart U937 cells were treated with SMLCL161 followed by assessment of cell death by PI staining and flow cytometry. SM treatment induced significant cell death in U1 cells but not in U937 cells (Fig 1A). To determine whether differentiation of U937 render these cells susceptible to SM-induced apoptosis, U937 and U1 cells were differentiated with PMA. Similar to the effect of SM on undifferentiated U1 cells, SM -LCL161 induced significant cell death in differentiated U1 cells but not in differentiated U937 cells (Fig 1B). Specific killing of HIV-infected U1 cells was further confirmed by showing cleavage of caspase-3 in U1 but not in U937 cells (Fig 1C).

\section{SMs induce cell death in in vitro HIV-infected MDMs and MDMs derived from HIV- infected patients}

To validate above findings in primary MDMs, we first verified the functional activity of SM by treating HIV-infected MDMs with LCL161 and observed degradation of both cIAP1 and cIAP2 


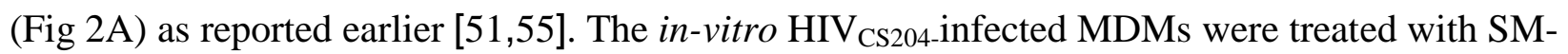

LCL161 followed by assessment of cell death by PI staining and flow cytometry. SM-LCL161 induced significant cell death of $\mathrm{HIV}_{\mathrm{CS} 204}$-infected MDMs but not in mock-infected MDMs (Fig 2B). Representative histograms of the intracellular PI staining are shown (Fig. 2C). The p24 values in MDMs infected with $\mathrm{HIV}_{\mathrm{CS} 204}$ for 7 days are shown in Fig 2D. Further, to determine whether M $\phi$ derived from HIV-infected individuals are similarly prone to SM-induced cell death, MDMs were generated from ART treated and ART naïve HIV-infected individuals and treated with SM-LCL161. Consistent with in vitro infection studies, ex vivo derived MDMs from treatment naïve and ART-treated HIV-infected individuals showed significantly increased susceptibility to SM-LCL161-induced cell death in a dose-dependent manner (Fig 2E).

Apoptosis has been shown to induce viral activation and replication in latently infected U1 and ACH2 cell lines [56]. In addition, Pache et al have shown that SMs can affect viral

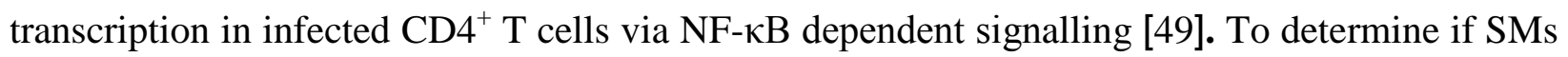
affect HIV replication in M $\phi$, in vitro HIV-infected MDM were treated with SM -LCL161 for 48 hr followed by analysis of p24 secretion. Interestingly, virus replication in primary HIV-infected MDM (Fig 2F) and in HIV-infected U1 cells (Fig 2G) was not affected by SM treatment.

\section{Smac mimetics specifically kill HIV-infected MDMs}

Based on above results, it is unclear if SMs are killing HIV-infected and/or bystander uninfected HIV-exposed MDM. To examine this, we employed a R5 laboratory strain of HIV-1, HIV-BalHSA, expressing mouse HSA (CD24). Expression of CD24 by HIV-infected cells can be used to identify infected cells by flow cytometry using FITC-conjugated anti-mouse HSA antibody [57]. 
MDMs were infected with HIV-Bal-HSA for 7 days followed by treatment with SM-AEG 40730 for another two days. Specific killing of HSA-expressing (HIV-infected) cells by SM-AEG 40730 was quantified by counter staining with Annexin-V labelled with BV-711. To rule out non-specific low level fluorescence by dead cells/debris, highly intense FITC positive HSAexpressing cells were gated and further quantified for Annexin- $\mathrm{V}$ expression. The gating strategy is shown in Fig. 3A. Quantification of Annexin-V positive, total (HSA+ and HSA-; Fig 3B, left panel) and intensely HSA+ MDMs (Fig 3C, left panel) revealed that SM-AEG 40730 killed significantly higher number of total HIV-infected (HSA+ and HSA-) and high HSAexpressing MDMs compared to the DMSO-treated HIV-infected cells. Representative histogram showing killing of total HSA+ and HSA- (Fig 3B, right panel) and intensely positive (Fig 3C, right panel) HSA-expressing cells is shown.

To determine whether SMs killed uninfected HIV-exposed bystander cells, MDM were infected with HIV-Bal-HSA for 7 days followed by treatment with either SM-AEG40730 or SMLCL161 for another two days. Specific killing of HSA-expressing (ie HIV-infected) and HSAnegative (HIV uninfected) cells by SM-AEG 40730 or SM-LCL161 was quantified by counter staining with BV-711 labelled Annexin-V as above. SM-AEG40730 and SM-LCL161 killed significantly high numbers of HIV-HSA-expressing (HIV-infected) cells compared to either the mock or HSA-negative (HIV-uninfected/bystander, HIV-exposed) cells (Fig 3 D). However, killing of HSA-negative (HIV-uninfected/bystander) cells was relatively higher than mockinfected cells but was not significant suggesting that SMs specifically kill HIV-infected M $\phi$.

Similar experiments were performed with a GFP-expressing HIV strain, HIV-eGFP. MDMs were infected with HIV-eGFP for 7 days followed by treatment with SM-AEG 40730 for two days. Expression of GFP by HIV-infected cells can be visualized by flow cytometry to 
identify infected cells. Specific killing of GFP-expressing (HIV-infected) cells by SM was quantified by counter staining with BV-711 labelled Annexin-V. Highly intense GFP positive cells were gated and further quantified for Annexin-V expression. The gating strategy is shown in Fig 4A. MDMs infected with HIV-GFP for 1-2 days could be detected by flow cytometry; however, MDMs infected for 7 days could not be detected as the virus multiplied for one round only (data not shown). Interestingly, treatment of HIV-GFP-infected cells with SM-AEG 40730 revealed killing of significantly high number of total HIV-GFP+ and GFP- MDMs compared to the DMSO-treated HIV-GFP-infected MDMs (Fig 4B, left panel). Specific killing of HIV-GFP infected cells by SM-AEG 40730 by gating dual GFP-positive and Annexin-V+ MDMs revealed that SM-AEG 40730 killed significantly higher number of intensely GFP+ HIV-infected cells compared to the DMSO-treated HIV-infected cells (Fig 4C, left panel). Representative histogram showing killing of total GFP+ and GFP- MDMs (Fig 4B right panel) and intensely GFP+, HIVGFP-infected cells (Fig 4C, right panel) by SM-AEG40730 is shown.

\section{Knocking down IAP genes results in specific killing of HIV-infected MDM}

To confirm the involvement of IAPs in SM-mediated killing of HIV-infected MDMs, we employed IAP-1/2 siRNAs as shown previously [50-52]. MDMs generated from PBMC from healthy donors were infected with HIV-Bal-HSA for 7 days followed by treatment with either non-targeting siRNA or IAP siRNAs for 72 hrs. Killing of HIV-infected cells in the presence of IAP siRNA treated cells was analyzed by staining with Annexin-V labelled with BV-711 as above. MDMs intensely expressing HSA and Annexin-V were gated and quantified as described above. The gating strategy is shown in Fig 5A. Quantification of Annexin-V positive total 
HSA+ and HSA- and intensely HSA-positive MDMs revealed that knocking down IAPs by siRNAs killed significantly higher number of total HIV-HSA+ and HSA- (HIV infected) MDMs

(Fig 5B, left panel) and intensely HSA+ MDMs (Fig 5C, left panel) compared to the control HIV-HSA-infected cells treated with non-targeting siRNAs. Representative histogram showing killing of total HSA+ and HSA- (Fig 5B, right panel) and intensely HSA positive (Fig 5C, right panel) MDMs is shown.

\section{SM-induced cell death in HIV-infected MDM is mediated by apoptosis}

To determine whether SM-induced cell death in in vitro HIV-infected MDM is due to apoptosis, caspase activation was quantified based on the fluorescent signal of cleaved caspase substrates.

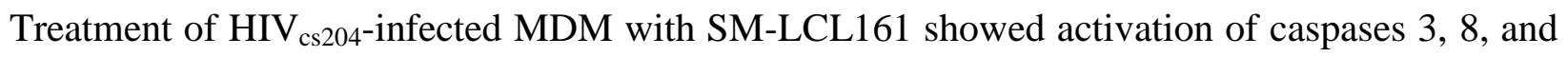
9 in contrast to the mock-infected MDM (Fig 6A-6C). Moreover, prior treatment with zVADFMK, a pan-caspase inhibitor, reduced the activation of caspase-8 and 9 after SM-LCL161 treatment (Fig 6B-C). A representative histogram for the induction of caspase 3, 8 and 9 following SM treatment of HIV-infected MDM is shown (supp. Fig 1).

\section{TNF- $\alpha$ mediates SM-induced apoptosis in U1 cells but not in primary HIV-infected MDM}

SM-induced cell death of various tumor cells is mediated by endogenously produced TNF- $\square$ following SM treatment through the activation of the non-canonical NF- $\mathrm{B}$ pathway $[58,59]$. To determine if SM-induced apoptosis in HIV-infected MDM is due to endogenous TNF $\alpha$ production, SM-LCL161-treated U937, U1 cells and in vitro HIV-infected primary MDM were 
analyzed for TNF- $\alpha$ secretion. SM-LCL161 treatment resulted in low level although significant TNF- $\alpha$ production in undifferentiated and differentiated U937 and U1 cells (Fig 7A-D) in contrast to both in vitro mock- and HIV-infected MDM (Fig 7E). Similarly, ex vivo derived MDM from HIV-infected patients did not produce significantly higher levels of TNF- $\alpha$ following SM-LCL161 treatment compared to the untreated negative controls (Fig 7F).

To evaluate the impact of TNF- $\alpha$ in SM-induced apoptosis of primary MDM, SMLCL161-treated MDM were stimulated with rTNF- $\alpha$ followed by analysis of cell death by PI staining. Treatment of MDMs with SM-LCL161 and TNFa did not result in cell death (Fig 7G). In contrast, rTNF- $\alpha$ either alone or in combination with SM-LCL161 induced significant cell death in U937 and U1 cells (Fig 7H, I) similar to that observed in various tumor cells [60,61]. These results suggest that SM-mediated killing of HIV-infected MDM is independent of TNF $\alpha$.

\section{HIV-infected MDM do not develop M1 phenotype before or after SM treatment}

Macrophages polarized with IFN $\gamma$ develop a M1 phenotype which is highly susceptible to SMinduced cell death (Supp. Fig 2). Therefore, it is possible that SM-induced cell death of HIVinfected MDMs is due to the development of M1 phenotype following HIV infection. To determine whether HIV-infected MDM develop M1 phenotype before or after SM treatment, cytokine array analysis for the following cytokines was performed: IL-17F, GM-CSF, IFN $\gamma$, IL10, CCL20/MIP3a, IL-12p70, IL-13, IL-15, IL-17a, IL-22, IL-9, IL-1ß, IL-33, IL-21, IL-23, IL5, IL-6, IL-17\&/IL-25, IL-27, IL-31, TNF $\alpha$, TNF $\beta$, and IL-28A. HIV-infected MDM secreted significantly high levels of CCL20/MIP3 $\alpha$, IL-6, and TNF $\alpha$ compared to the mock control. There was no significant difference in the secretion of IL-10, IL-21, IL-13, and IL-23 between 
the HIV-infected and mock-infected controls (Supp. Fig 3). Remaining cytokines were not detected in either group suggesting that HIV infection of MDMs does not result in the upregulation of cytokines related to M1 phenotype. SM treatment did not affect the secretion of above mentioned cytokines including CCL20/MIP3 $\alpha$, IL-6, IL-23, IL-10, IL-21, IL-13, and TNFa in in-vitro HIV-infected MDMs (Supp. Fig 4) or in ex-vivo derived MDMs from HIVinfected patients (Supp. Fig 5). These results suggest that in-vitro HIV-infected MDM either before or after SM treatment did not express M1 phenotype and SM-mediated apoptosis of HIVinfected MDM is independent of M1-polarization.

\section{HIV-infection downregulates RIPK1 in MDMs}

SM-induced apoptosis of HIV-infected macrophages may be ascribed to the impaired expression of IAP-associated signalling kinases such as RIPK-1 $[62,63]$. RIPK-1 plays a key role in the regulation of various cellular processes such as NF- $\mathrm{B}$ signalling and apoptosis [64]. Moreover RIPK-1 is a target substrate for HIV protease, a viral protein that is synthesized late in the viral life cycle and inactivates RIPK1 in HIV-infected primary CD4+ T cells [65]. To determine whether RIPK1 is similarly cleaved and inactivated in HIV-infected MDMs, in vitro mock and

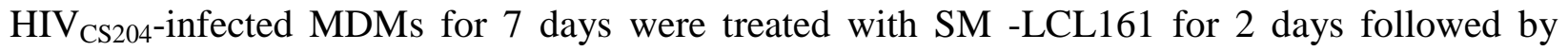
immunoprobing for RIPK-1. HIV infection resulted in the downregulation of RIPK-1 in the presence and absence of SM-LCL161 compared to the mock infected controls (Fig 8A). This was also demonstrated by in vitro infection of MDMs with $\mathrm{HIV}_{\mathrm{CS} 204}$ for 2-8 days. Infection with HIV $_{\text {CS204 }}$ resulted in cleavage of RIPK1 with a relative decrease in full length RIPK1 while the cleaved RIPK1product gradually increased over time (Fig 8B). 
To confirm the downregulation of RIPK-1 in HIV-infected MDM, MDMs were infected with HIV-Bal-HSA. After 9 days of infection, HIV-infected HSA-expressing MDMs were harvested by magnetic column separation based on HSA expression followed by immunoblotting for RIPK-1 analysis [57]. The negative fraction represents HIV-exposed uninfected cells that do not express HSA on their surface, and hence get eluted after the first passing of the labelled cells. Waste fraction represents cells that are eluted during the column wash prior to the collection of the HSA-selected MDM. The positive fraction represents the HIV-infected HSA-expressing cells retained in the magnetic column that are eluted at the end of the HSA-selection protocol. The gating strategy for detection of HIV-HSA infected macrophages is shown in Fig 8C left panel. The positively selected MDM infected with HIV-HSA showed $70 \%$ purity while the negatively selected HIV-uninfected cells and waste fractions had $\sim 7 \%$ and $\sim 10 \%$ contaminating HSA expressing MDMs, respectively (Fig 8C, right panel). The results show that RIPK1 was downregulated in the positively selected HIV-HSA enriched fraction compared to the mock infected and negatively selected HIV-uninfected MDM (Fig 8D). These results indicate that RIPK1 degradation is a consequence of HIV infection of primary MDM.

\section{SM treatment of HIV-infected MDMs downregulates apoptosis associated signalling molecules TRAF-1 and Bid}

In addition to RIPK-1, the process of apoptosis requires the fine-tuned functionality of several signalling molecules including TRAF-1/2, as well as proteins that regulate homeostasis of mitochondria such as Bid and Bax [64,66-68]. We determined the expression of these signalling molecules in response to SM-LCL161 treatment of in vitro $\mathrm{HIV}_{\mathrm{CS} 204}$-infected MDM. HIV 
infection resulted in the down regulation of TRAF-1 (Fig 8E, lanes 1 and 4). Treatment of HIVinfected MDM with SM-LCL161 also resulted in the downregulation of TRAF-1 compared to the mock infected and SM-treated MDMs (Fig 8E lanes 2, 3 and 5). However, TRAF-2 and Bax did not show a significant change in their expression in mock- and HIV-infected MDM as well as between SM-LCL161 treated mock and HIV-infected MDMs (Fig 8E). Bid was downregulated with increasing concentration of SM-LCL161 in the HIV-infected MDM but not in mock-infected MDM (Fig 8E). Overall, these results suggest that SM dysregulates the expression of apoptosis-associated TRAF-1 and Bid in HIV-infected MDM.

\section{cIAP1/2 and RIPK-1 are essential for survival of MDM}

The above results showing inactivation of RIPK1 in settings where cIAPs are absent, may affect the viability of MDM. To determine the combined impact of knockdown of cIAPs and RIPK-1 in the survival of MDM, MDMs from healthy donors were pretreated with necrostatin-1, a specific RIPK-1 inhibitor, for 2 hr followed by treatment with SM-LCL161 and analysis for cell death. Treatment with SM-LCL161 or necrostatin-1 alone did not induce significant cell death of normal primary MDMs. However, combination treatment of SM-LCL161 and necrostatin-1 resulted in significant increase in cell death of primary MDM (Fig 9A). Figure 9B shows representative histograms of the intracellular PI stain. Moreover, treatment with necrostatin-1 alone did not show cleavage of PARP or caspases-8 and 9 although treatment with SM-LCL161 alone did show their minimal cleavage (Fig 9C). However, treatment with both necrostatin-1 and SM-LCL161 revealed significantly enhanced cleavage of the three caspases as well as PARP. These results suggest that cIAP1/2 and RIPK-1 play an important role in regulating viability of 
bioRxiv preprint doi: https://doi.org/10.1101/543017; this version posted February 6,2019 . The copyright holder for this preprint (which was not certified by peer review) is the author/funder, who has granted bioRxiv a license to display the preprint in perpetuity. It is made available under aCC-BY 4.0 International license.

primary human MDM. Since HIV infection down regulates RIPK-1 in MDMs and degradation of IAPs with SM-LCL161 results in death of HIV-infected MDM suggest that RIPK-1 and IAPs play crucial roles in SMs-induced cell death of HIV-infected MDM. 


\section{Discussion}

In this study, we investigated the role of IAPs in resistance to apoptosis of HIV-infected M $\phi$. We show that although cIAP1/2 are dispensable host factors for the viability of M $\phi$, it plays a critical role in the survival of HIV-infected $\mathrm{M} \phi$. This is illustrated by the observation that SMs induce apoptosis of chronically HIV-infected U1 cell line, in vitro HIV-infected MDMs, and ex-vivo derived MDMs from naïve and ART-treated HIV patients. SMs were shown to specifically kill HIV-infected MDMs by employing a HSA expressing R5-laboratory strain, HIV-Bal-HSA, and GFP-expressing, HIV-eGFP. The involvement of IAPs was confirmed by employing IAP siRNAs that resulted in killing of HIV-infected MDMs. Our data suggests that SM-induced apoptosis of HIV-infected $\mathrm{M} \phi$ is mediated by apoptosis, is independent of TNF- $\alpha$ and the establishment of M1 polarization. Furthermore, SM-induced apoptosis of HIV-infected M $\phi$ may be due to RIPK-1 degradation which in concert with IAP1/2 degradation results in apoptosis of HIV-infected M $\phi$.

To achieve eradication of HIV-1 in patients undergoing suppressive ART, it is imperative to devise strategies to eliminate HIV reservoirs in cell targets other than T cells such as $\mathrm{M} \phi$. Recently, IAPs were shown as a potent negative regulator of LTR-dependent HIV-1 transcription and leading to the reversal of HIV latency in JLat latency model system and primary T cells [49]. In addition, IAP1/2 and survivin, another member of the IAP family were suggested to be involved in survival of HIV-infected CD4+ T cells [46,47]. SM activate the non-canonical NFผB pathway by virtue of RelA:p50 and RelB:p52 transcription factors which bind to the HIV-1 LTR region and results in the induction of virus transcription in latently infected JLat cell lines 
[49,69]. In addition, XIAP down regulation by flavopiridol, a cyclin-dependent kinase 9 (CDK9) inhibitor, resulted in increased apoptosis of ACH2 cells (a chronically HIV-infected T cell line) [70]. Additionally, ablation of cIAP1/2 by SMs cleared hepatitis B virus in immune competent mouse models [48]. We and others have previously shown that ablation of cIAP1/2 by SMs does not affect survival of normal primary human $\mathrm{M} \phi[51,71]$. However, resistance of $\mathrm{M} \phi$ to apoptogenic HIV-Vpr was attributed to cIAP1/2 [51]. These observations suggest that targeting of IAPs may represent a possible strategy for killing of HIV-infected M $\phi$. Herein, we show that in vitro HIV-infected MDM and MDM generated ex vivo from ART-treated or naïve HIV-infected patients were highly susceptibility to SM-mediated cell death. Induction of apoptosis was confirmed by using monomeric (LCL161) and dimeric (AEG40730) SMs as well as IAP-siRNAs and three different M-tropic strains including HIV $_{\text {cs204 }}$ (clinical), HIV-eGFP and HIV-Bal-HSA. The high variability in the degree of SM-mediated killing of ex vivo generated MDM in ART-treated and naïve untreated groups may be due to the effects of antiretroviral drugs on mitochondrial function and highly variable percentage of HIV-infected monocytes in the patients $[72,73]$. The CD16+ monocytes in the ART-treated patients are significantly higher compared to the untreated group and CD16+ monocytes are more permissive to infection and preferentially harbors HIV-1 in vivo [7].

The number of HIV infected M $\phi$ in in vitro infected MDMs is around 5-10\% due partly to a milieu of HIV restriction factors that limit the virus life cycle $[57,74-76]$. However, some of our experiments show killing of around 30\% of M $\phi$ suggesting that SM may cause non-specific killing of bystander MDMs. Since SM did not significantly inhibit virus replication, it is possible that HIV proteins such as Vpr secreted in the supernatants [77] may prime bystander MDMs to SM-mediated killing [50-52]. By employing HIV-Bal-HSA and HIV-GFP strains, our results 
show that SMs are specifically killing HIV-infected macrophages. Although SM are killing relatively higher number of HIV-HSA-negative MDMs compared to mock-infected MDMs, the differences were not significant. Moreover, SMs killed significantly higher number of HIVHSA-infected MDMs compared to the HIV-HSA-negative MDMs further suggests the specificity of SMs towards killing of HIV-infected macrophages. cIAP1 was shown to be a negative regulator of LTR-dependent HIV-1 transcription in latently infected primary memory T cells [49]. However, SM did not affect HIV transcription in U1 cells and in vitro HIV-infected MDM. We have previously shown that SM treatment alone did not activate either classical or alternative NF- $\mathrm{BB}$ pathways in $\mathrm{M} \phi$ [55] that may explain SM's inability to impact virus replication in $\mathrm{M} \phi$.

Our results suggest that the mechanism of SM-mediated killing of HIV-infected MDMs is independent of endogenous TNF- $\alpha$. SM-mediated killing has been attributed to endogenous TNF- $\alpha$ in cancer cells $[58,59]$; however, it has been reported to be independent of TNF- $\alpha$ in some cancer cells [78]. Given that M $\phi$ produce high levels of TNF $\alpha$, the possibility that SMmediated killing of HIV-1-infected MDM could be attributed to TNF- $\alpha$ was investigated. TNF- $\alpha$ mediated SM-induced killing of myeloid U1 and U937 undifferentiated and PMA-differentiated cells in contrast to that of primary MDMs Although the in vitro HIV-infected MDM produced significant amounts of TNF $\alpha$ compared to the mock-infected MDMs, SM treatment did not affect TNF- $\alpha$ secretion in either uninfected or HIV-infected MDM. Moreover, rTNF- $\alpha$ failed to induce cell death in SM-treated MDM suggesting that SM-induced cell death in M $\phi$ contrary to the cancer cells is independent of TNF- $\alpha$ further displaying dichotomy in the effects of SMs on leukemic myeloid cells and primary macrophages. 
HIV infection results in dysregulation of cytokine profile in vivo and in vitro [79] and can possibly affect the polarization state of M $\phi$. Since IFN $\gamma$-generated M1 M $\phi$ are highly susceptible to SM-mediated cell death, the possibility of in vitro HIV-1 infection to polarize M $\phi$ into M1 phenotype making these cells susceptible to SM-induced apoptosis was studied. We show that in vitro infected and ex vivo derived MDM exposed to SM were not polarized into M1 phenotype suggesting that SM-mediated killing of HIV infected M $\phi$ was not due to M1 polarization.

Our results suggest that the mechanism of SM-mediated selective killing of U1 cells and primary MDM infected with the clinical strain, HIV $_{\mathrm{cs} 204}$ is via apoptosis. The pathways of apoptosis are regulated by RIPK-1 [64,67]. In TNF $\alpha$-mediated signalling, RIPK-1 is recruited in a multiprotein complex I along with TRADD, TRAF2, and cIAP1/2 to promote transcription of genes with anti-apoptotic properties such as cIAP1/2 [67]. RIPK1 is also recruited in a protein complex composed of TRADD, FADD, and caspase-8, which depending on additional proteins recruited, can induce apoptosis or necroptosis [67]. Recently, HIV infection of primary activated $\mathrm{CD}^{+} \mathrm{T}$ cells was shown to downregulate RIPK-1 through HIV-1 protease [65]. RIPK-1 modification in response to human rhinovirus and Newcastle disease virus infection has also been reported $[80,81]$. Herein, we show that infection of MDM with HIV-cs204 or with HIV-BalHSA caused downregulation and cleavage of RIPK-1. Given that down regulation of IAPs alone by SM LCL161 or of RIPK-1 alone by necrostatin did not induce cell death in uninfected MDM, suggests that RIPK-1 and IAP1/2 are dispensable in survival of M $\phi$. However, inactivation of RIPK-1 by necrostatin-1 following IAP degradation by SM resulted in a dramatic increase in cell death, cleavage of caspases and PARP in normal MDM suggesting that RIPK-1 may play a key role in SM-induced killing of HIV-infected M $\phi$. The role of RIPK-1 degradation during HIV-1 infection of $\mathrm{M} \phi$ needs further investigation. 
TRAF1 is an important receptor interacting protein that forms a complex with TRAF2 to transduce TNF $\alpha$-induced MAPK and NF- $\kappa \mathrm{B}$ activation [82]. TRAF2 is also a key determinant for SM-induced degradation of cIAP1/2 [82]. Our results show that in vitro HIV infection as well as SM-treatment of HIV-infected MDM resulted in downregulation of TRAF-1 but not of TRAF2. In addition, Bid, a proapoptotic protein, is downregulated in SM-treated MDM. Bid is localized in an inactive form in the cytosol which becomes activated by proteolytic cleavage of active caspase-8 [68]. Upon activation, cleaved Bid translocates to mitochondria and forms a complex with Bax to disrupt its integrity resulting in the release of apoptogenic factors, caspase3 activation and cell death. How SMs cause down regulation of Bid and TRAF-1 in HIV-infected macrophages is not clear. We have shown previously that HIV-Vpr targets Bid, TRAF1 and TRAF2 for proteosomal degradation leading ultimately to mitochondrial outer membrane depolarization and apoptosis [52]. Since SM did not inhibit virus replication and that HIV-Vpr is one of the early genes expressed in virus life cycle, and HIV-Vpr is released following in vitro infection of $\mathrm{M} \phi$, the interplay between Vpr and SM-mediated effect may lead to down regulation of Bid and TRAF-1 and cell death of HIV-infected M $\phi$. The functional relevance of the modulation of apoptosis related genes in response to SM-treatment of HIV-infected M $\phi$ needs further investigation.

In summary, the results of this study suggest the potential significance of SM in killing of HIV-infected M $\phi$ in vivo. In the event SM are able to kill HIV-infected M $\phi$ in vivo, they have the potential to be translated into clinical interventions aimed at eradicating HIV infection by directly targeting HIV-infected $\mathrm{M} \phi$. 


\section{Materials and methods}

\section{Generation of human monocyte-derived macrophages (MDM), cell lines and reagents}

Human peripheral blood mononuclear cells (PBMCs) were isolated by density gradient centrifugation using Ficoll Paque (GE Healthcare Life Sciences Buckingmshire, UK) from the blood of healthy donors. Human MDMs were generated from monocytes via adherence methods as previously described [55]. Briefly, 2.0x10 ${ }^{6}$ PBMCs/well were allowed to adhere for 3 hr and non-adherent cells were washed off. Adherent monocytes were cultured for 7 days in complete DMEM (Wisent Inc., St. Bruno, Quebec) medium supplemented with 10\% fetal bovine serum (FBS; GE Healthcare), penicillin and streptomycin and $10 \mathrm{ng} / \mathrm{mL}$ MCSF (R\&D Systems, Minneapolis, MN, USA). MCSF-containing media was replaced every 2 days until the $7^{\text {th }}$ day at which point the monocytes differentiated into macrophages. Purity of macrophages as assessed by measuring CD14 expression by flow cytometry was $100 \%$.

U937 and U1 cells were obtained from NIH AIDS reagent program and were cultured in complete DMEM media. For differentiation, 5.0x10 $10^{5}$ 937 and U1 cells were treated with $20 \mathrm{nM}$ PMA (Sigma Aldrich, St. Louis, Missouri, USA) for 2 days. The smac mimetics (SM) LCL161 (Active BIochem, Hongkong), and AEG40730 (Tocris Bioscience, Bristol, UK), necrostatin-1 (ApexBio, Houston, TX, USA), staurosporine (ApexBio, Houston, Texas, USA), and LPS (Sigma Aldrich, St. Louis, Missouri, USA) were purchased. 


\section{HIV-1 production and infection of MDMs}

The dual tropic HIV-cs204 was a gift from Dr. J. Angel (The Ottawa Hospital, Ottawa, ON, Canada). HIV $\mathrm{CS}_{204}$ stocks were produced in $\mathrm{CD}^{+}$depleted PBMCs from healthy donors as described earlier [83]. Stocks of mock virus were produced under similar conditions but in the absence of HIV. HIV growth was determined by measuring p24 using HIV-1 p24 ${ }^{\mathrm{CA}}$ capture kit as per the manufacturer’ directions (AIDS \& Cancer Virus Program, NCI, Fredrick, MD).

The plasmids HIV Gag-iGFP_JRFL (NIH) and pUC-19 (Thermo Fisher Scientific, Waltham, MA, USA) were purchased. The plasmid pNL4.3-Bal-IRES-HSA (provided by Dr M. Tremblay, Laval University, Quebec, Canada) was amplified using One $\operatorname{Shot}^{\circledR}$ Stbl3 $^{\mathrm{TM}}$ competent E. coli (Invitrogen, Carlsbad, CA, USA) and isolated using endotoxin-free plasmid DNA isolation mega

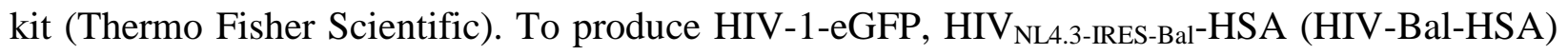
and mock viruses, $50 \mu \mathrm{g}$ endotoxin-free plasmid DNA were transfected into 293T cells with 125 $\mu \mathrm{l}$ of Lipofectamine 2000 (Invitrogen) at a density of 18.0 x10 cells/T150 Dish. The supernatants harvested at 48 and $72 \mathrm{hr}$ were combined and centrifuged at $2000 \mathrm{~g}$ for $15 \mathrm{~min}$. PEG-it ${ }^{\mathrm{TM}}$ virus precipitation solution (SBI, Biotech, Japan) was used to precipitate viruses at $4^{\circ} \mathrm{C}$ for 24 48 hr and centrifuged at $2000 \mathrm{~g}$ for $30 \mathrm{~min}$. The precipitates were resuspended in PBS with 0.05M HEPES and stored at $-80^{\circ} \mathrm{C}$. Viruses were quantified by HIV p24 ELISA as above.

The MDMs were infected with 100 ng p24 per $1.0 \times 10^{6}$ cells supplemented with $5 \mu \mathrm{g} / \mathrm{mL}$ polybrene (Sigma Aldrich) for $16 \mathrm{hr}$ following which cells were infected with $\mathrm{HIV}_{\mathrm{CS} 204}$, HIVBal-HSA or HIV-eGFP for 7 days. The supernatants were assessed for p24 using HIV p24 ${ }^{\text {CA }}$ ELISA capture kit as above. 


\section{Treatment of MDM with SM or siRNA and assessment of apoptosis}

MDMs were cultured in complete media without antibiotics for $2 \mathrm{hr}$ before treatment with various concentrations of SM-AEG40730 or SM-LCL161. For siRNA treatment, $20 \mathrm{nM}$ of siRNA mixture (XIAP, cIAP1 and cIAP2) was added to $200 \mu \mathrm{l}$ of Opti-MEM ${ }^{\mathrm{TM}}$ I Reduced Serum Medium with $1.0 \mu$ l DharmaFect 3 (Dharmacon, Colorado, USA). MDMs were evaluated for cell death by using intracellular PI staining as described [51,84]. Briefly, cells were washed with PBS and fixed with methanol for 15 min at $4{ }^{\circ} \mathrm{C}$. Subsequently, cells were treated with 25 $\mu \mathrm{l}$ of $10 \mu \mathrm{g} / \mathrm{ml}$ RNase A, followed by staining with $25 \mu \mathrm{l}$ of $1 \mathrm{mg} / \mathrm{ml}$ PI solution (Sigma-Aldrich) at $4{ }^{\circ} \mathrm{C}$ for $1 \mathrm{~h}$. The DNA content was analyzed using a FACSCanto flow cytometer (BD Biosciences, Franklin Lakes, NJ, USA) and the FACSDiva software. The subdiploid DNA peak ( $<2 \mathrm{~N}$ DNA), immediately adjacent to the $\mathrm{G}_{0} / \mathrm{G}_{1}$ peak (2N DNA), represents apoptotic cells and was quantified by histogram analyses. PI histograms figures were obtained with WinMDI version 2.8 software (J. Trotter, Scripps Institute, San Diego, CA).

For quantification of apoptosis in HIV-HSA- or HIV-GFP-infected MDMs following treatment with either SM or siRNA transfection, cells were harvested after trypsinization with 0.25\% Trypsin-EDTA (Gibco, Dublin, Ireland) for $30 \mathrm{~min}$. HIV-eGFP-infected MDMs were stained with 2.0 $\mu$ l Annexin-V-APC (BD Biosciences) in $50 \mu$ of PBS/0.5\% BSA for 15 min, and fixed with 1\% PFA (Affymetrix, Santa Clara, CA, USA). Cells were analyzed with flow cytometer (BD LSR FORTESSA X-20) in GFP and APC channels. HIV-Bal-HSA-infected MDMs were blocked with FcR blocking reagent (MACS Miltenyi Biotec, Auburn, CA, USA) in $50 \mu \mathrm{l}$ of PBS/0.5\% BSA, and stained with $2.0 \mu \mathrm{l}$ of FITC conjugated anti-mouse CD24 antibody 
(BD Biosciences) for 20 min. Cells were washed and stained with Annexin-V-APC for 15 min, fixed with 1\% PFA followed by analysis with flow cytometer at FITC and APC channels.

\section{Isolation of HIV-HSA-infected MDMs}

MDMs were infected with HIV-Bal-HSA for 9 days followed by magnetic sorting using HSACD24 beads (MACS Miltenyi Biotec.) through column separation, as previously described [57]. Briefly, infected MDMs were detached with accutase (Innovative Cell Technologies, San Diego, CA), FcR $\gamma$ II receptors were blocked with FcR blocker (MACS Miltenyi Biotec), stained with primary CD24-biotin conjugated antibody and incubated with anti-biotin ultra pure microbeads (MACS Miltenyi Biotec). HSA-expressing cells were collected by positive selection in LS columns. The HSA-negative (negative fraction) cells were collected after passing the labelled cells through the column for the first time. The column was detached from the magnet and the HSA positively labelled cells were collected by plunging out the cells. Purity of the HSAinfected macrophages was assessed by flow cytometry using anti-Biotin PECy7 antibody.

\section{Analysis of caspase activation}

Activation of caspase-3, -8, and -9 was measured as per Abcam's Caspase staining kit protocol (Abcam, Toronto, Ontario, Canada) by flow cytometry.

\section{TNF- $\alpha$ ELISA and cytokine ELISA array}


Human TNF- $\alpha$ duo set (R\&D System) was used to quantify TNF- $\alpha$ as per the manufacturer recommendations. Briefly, the 96-well plates were preincubated with TNF- $\alpha$ capture antibody for $16 \mathrm{hr}$ followed by blocking with $1 \% \mathrm{FBS}$. TNF $\alpha(1-1000 \mathrm{pg} / \mathrm{mL})$ was used as standards. The samples were added to the plates for $16 \mathrm{hr}$ followed by the detection antibodies for two hr. Next, 100uL/well of substrate solution was added. The enzymatic reaction was stopped with 50 uL/well of stop solution (BioFX Labs, Owing Mills, MD). The plates were read at $490 \mathrm{nM}$ using iMark Microplate reader (Biorad, Mississauga, Ontario) using microplate manager 6 software.

The levels of secreted cytokines were measured as per the directions in Milliplex map kit (Millipore, Etobicoke, ON, Canada). IL-17F, GM-CSF, IFN $\gamma$, IL-10, CCL20/MIP3a, IL-12p70,

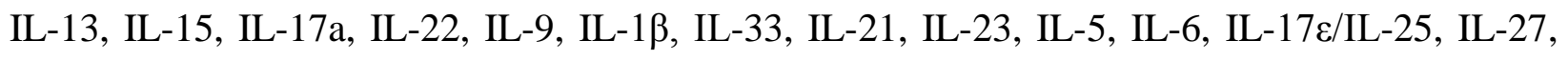
IL-31, TNF $\alpha$, TNF $\beta$, and IL-28A were detected using antibody-immobilized magnetic beads and were quantified by MAGPIX ${ }^{\circledR}$ multiplex with xPONENT® software (Luminex Corp.).

\section{Western immunoblot analysis}

The lysates were subjected to SDS-PAGE electrophoresis as described earlier $[51,55,84]$. Proteins were transferred onto polyvinylidene difluoride membrane (BioRad Laboratory, Hercules, CA) and probed with primary antibodies specific for cIAP1, cIAP2, XIAP, caspase-3, caspase-8, caspase-9, $\beta$-actin, PARP, Bax, TRAF-1, TRAF-2, and RIPK-1 (Cell Signalling Tech, Inc., Danvers, MA), followed by goat anti-rabbit or anti-mouse secondary polyclonal antibodies conjugated to horseradish peroxidase (BioRad Laboratory). Proteins were visualized by enhanced chemiluminescence (Amersham Bioscience, Little Chalfont, UK). 


\section{Statistical analysis}

Data was plotted using Graphpad Prism 5. Statistical significance was calculated using student t test or One-way Anova, followed by Dunnett post test. Plotted data represent the mean \pm SD.

\section{Ethics statement}

Healthy participants involved in the study gave informed written consent and the protocol for obtaining blood samples was approved by the Review Ethics Board of the Ottawa General Hospital and the Children’s Hospital of Eastern Ontario, Ottawa, ON, Canada. 


\section{Acknowledgements}

This study was supported by grants from the Canadian Institute of Health Research to AK (HOP 98830; HOP-107542) and by The Canadian HIV Cure Enterprise Team Grant HIG-133050 (AK) from the CIHR in partnership with CANFAR and IAS. RC was supported by a scholarship from the destination 2020 Faculty of Medicine, University of Ottawa, Ontario, Canada. We acknowledge the generous help provided by the nurses in collecting blood samples. We also acknowledge the healthy donors and HIV patients for providing their blood samples.

The authors declare no conflicting financial interests.

\section{Authors Contribution:}

RC, SD and NG performed and analyzed experiments, RC wrote the manuscript, HA performed experiments, EC and JA provided critical insights in writing the manuscripts, JA and WC provided clinical samples, RK provided reagents, MT provided HSA and GFP labelled HIV strains, AK designed the project, analyzed experiments and wrote the manuscript 
References

1. Kumar A, Abbas W, Herbein G (2014) HIV-1 latency in monocytes/macrophages. Viruses 6: 1837-1860.

2. Redel L, Le D, V, Cherrier T, Marban C, Janossy A, Aunis D, Van LC, Rohr O, Schwartz C (2010) HIV-1 regulation of latency in the monocyte-macrophage lineage and in CD4+ T lymphocytes. J Leukoc Biol 87: 575-588.

3. Honeycutt JB, Wahl A, Baker C, Spagnuolo RA, Foster J, Zakharova O, Wietgrefe S, CaroVegas C, Madden V, Sharpe G, Haase AT, Eron JJ, Garcia JV (2016) Macrophages sustain HIV replication in vivo independently of T cells. J Clin Invest 84456.

4. Arainga M, Edagwa B, Mosley RL, Poluektova LY, Gorantla S, Gendelman HE (2017) A mature macrophage is a principal HIV-1 cellular reservoir in humanized mice after treatment with long acting antiretroviral therapy. Retrovirology 14: 17-0344.

5. Sonza S, Mutimer HP, Oelrichs R, Jardine D, Harvey K, Dunne A, Purcell DF, Birch C, Crowe SM (2001) Monocytes harbour replication-competent, non-latent HIV-1 in patients on highly active antiretroviral therapy. AIDS 15: 17-22.

6. Crowe SM, Sonza S (2000) HIV-1 can be recovered from a variety of cells including peripheral blood monocytes of patients receiving highly active antiretroviral therapy: a further obstacle to eradication. J Leukoc Biol 68: 345-350.

7. Ellery PJ, Tippett E, Chiu YL, Paukovics G, Cameron PU, Solomon A, Lewin SR, Gorry PR, Jaworowski A, Greene WC, Sonza S, Crowe SM (2007) The CD16+ monocyte subset is more permissive to infection and preferentially harbors HIV-1 in vivo. J Immunol 178: 6581-6589.

8. Crowe S, Zhu T, Muller WA (2003) The contribution of monocyte infection and trafficking to viral =. J Leukoc Biol 74: 635-641.

9. Perelson AS, Neumann AU, Markowitz M, Leonard JM, Ho DD (1996) HIV-1 dynamics in vivo: virion clearance rate, infected cell life-span, and viral generation time. Science 271: 1582-1586.

10. Smith PD, Meng G, Salazar-Gonzalez JF, Shaw GM (2003) Macrophage HIV-1 infection and the gastrointestinal tract reservoir. J Leukoc Biol 74: 642-649.

11. Yukl SA, Sinclair E, Somsouk M, Hunt PW, Epling L, Killian M, Girling V, Li P, Havlir DV, Deeks SG, Wong JK, Hatano H (2014) A comparison of methods for measuring rectal HIV levels suggests that HIV DNA resides in cells other than CD4+ T cells, including myeloid cells. AIDS 28: 439-442.

12. Gonzalez-Scarano F, Martin-Garcia J (2005) The neuropathogenesis of AIDS. Nat Rev Immunol 5: 69-81. 
13. Igarashi T, Brown CR, Endo Y, Buckler-White A, Plishka R, Bischofberger N, Hirsch V, Martin MA (2001) Macrophage are the principal reservoir and sustain high virus loads in rhesus macaques after the depletion of CD4+ $\mathrm{T}$ cells by a highly pathogenic simian immunodeficiency virus/HIV type 1 chimera (SHIV): Implications for HIV-1 infections of humans. Proc Natl Acad Sci U S A 98: 658-663.

14. Aquaro S, Bagnarelli P, Guenci T, De LA, Clementi M, Balestra E, Calio R, Perno CF (2002) Long-term survival and virus production in human primary =. J Med Virol 68: 479-488.

15. Fernandez Larrosa PN, Croci DO, Riva DA, Bibini M, Luzzi R, Saracco M, Mersich SE, Rabinovich GA, Martinez PL (2008) Apoptosis resistance in HIV-1 persistentlyinfected cells is independent of active viral replication and involves modulation of the apoptotic mitochondrial pathway. Retrovirology 5:19. doi: 10.1186/1742-4690-519.: 19-5.

16. Delobel P, Sandres-Saune K, Cazabat M, L'Faqihi FE, Aquilina C, Obadia M, Pasquier C, Marchou B, Massip P, Izopet J (2005) Persistence of distinct HIV-1 populations in blood monocytes and naive and memory CD4 T cells during prolonged suppressive HAART. AIDS 19: 1739-1750.

17. Mlcochova P, Sutherland KA, Watters SA, Bertoli C, de Bruin RA, Rehwinkel J, Neil SJ, Lenzi GM, Kim B, Khwaja A, Gage MC, Georgiou C, Chittka A, Yona S, Noursadeghi M, Towers GJ, Gupta RK (2017) A G1-like state allows HIV-1 to bypass SAMHD1 restriction in macrophages. EMBO J 36: 604-616.

18. Gillim-Ross L, Cara A, Klotman ME (2005) HIV-1 extrachromosomal 2-LTR circular DNA is long-lived in human macrophages. Viral Immunol 18: 190-196.

19. Pang S, Koyanagi Y, Miles S, Wiley C, Vinters HV, Chen IS (1990) High levels of unintegrated HIV-1 DNA in brain tissue of AIDS dementia patients. Nature 343: 85-89.

20. Badley AD, Sainski A, Wightman F, Lewin SR (2013) Altering cell death pathways as an approach to cure HIV infection. Cell Death Dis 4:e718. doi: 10.1038/cddis.2013.248.: e718.

21. Coleman CM, Wu L (2009) HIV interactions with monocytes and dendritic cells: viral latency and reservoirs. Retrovirology 6:51. doi: 10.1186/1742-4690-6-51.: 51-56.

22. McElrath MJ, Steinman RM, Cohn ZA (1991) Latent HIV-1 infection in enriched populations of blood monocytes and T cells from seropositive patients. J Clin Invest 87: 27-30.

23. Zhu T, Muthui D, Holte S, Nickle D, Feng F, Brodie S, Hwangbo Y, Mullins JI, Corey L (2002) Evidence for human immunodeficiency virus type 1 replication in $=$. J Virol 76: 707-716.

24. Watters SA, Mlcochova P, Gupta RK (2013) Macrophages: the neglected barrier to eradication. Curr Opin Infect Dis 26: 561-566.

25. Graziano F, Vicenzi E, Poli G (2016) Immuno-Pharmacological Targeting of Virus-Containing Compartments in HIV-1-Infected Macrophages. Trends Microbiol 24: 558-567. 
26. Inlora J, Chukkapalli V, Bedi S, Ono A (2016) Molecular Determinants Directing HIV-1 Gag Assembly to Virus-Containing Compartments in Primary Macrophages. J Virol 90: 85098519.

27. Koppensteiner H, Banning C, Schneider C, Hohenberg H, Schindler M (2012) Macrophage internal HIV-1 is protected from neutralizing antibodies. J Virol 86: 2826-2836.

28. Sharova N, Swingler C, Sharkey M, Stevenson M (2005) Macrophages archive HIV-1 virions for dissemination in trans. EMBO J 24: 2481-2489.

29. Duncan CJ, Williams JP, Schiffner T, Gartner K, Ochsenbauer C, Kappes J, Russell RA, Frater J, Sattentau QJ (2014) High-multiplicity HIV-1 infection and neutralizing antibody evasion mediated by the macrophage-T cell virological synapse. J Virol 88: 2025-2034.

30. Sattentau QJ, Stevenson M (2016) Macrophages and HIV-1: An Unhealthy Constellation. Cell Host Microbe 19: 304-310.

31. Avalos CR, Price SL, Forsyth ER, Pin JN, Shirk EN, Bullock BT, Queen SE, Li M, Gellerup D, O'Connor SL, Zink MC, Mankowski JL, Gama L, Clements JE (2016) Quantitation of Productively Infected Monocytes and Macrophages of Simian Immunodeficiency VirusInfected Macaques. J Virol 90: 5643-5656.

32. Stevenson M (2017) HIV persistence in macrophages. Nat Med 23: 538-539.

33. Avalos CR, Abreu CM, Queen SE, Li M, Price S, Shirk EN, Engle EL, Forsyth E, Bullock BT, Mac GF, Wietgrefe SW, Haase AT, Zink MC, Mankowski JL, Clements JE, Gama L (2017) Brain Macrophages in Simian Immunodeficiency Virus-Infected, AntiretroviralSuppressed Macaques: a Functional Latent Reservoir. MBio 8: e01186-17.

34. Clayton KL, Garcia JV, Clements JE, Walker BD (2017) HIV Infection of Macrophages: Implications for Pathogenesis and Cure. Pathog Immun 2: 179-192.

35. Cenker JJ, Stultz RD, McDonald D (2017) Brain Microglial Cells Are Highly Susceptible to HIV-1 Infection and Spread. AIDS Res Hum Retroviruses 10.

36. DiNapoli SR, Ortiz AM, Wu F, Matsuda K, Twigg HL, III, Hirsch VM, Knox K, Brenchley JM (2017) Tissue-resident macrophages can contain replication-competent virus in antiretroviral-naive, SIV-infected Asian macaques. JCI Insight 2: e91214.

37. Hassan J, Browne K, De GC (2016) HIV-1 in Monocytes and Macrophages: An Overlooked Reservoir? Viral Immunol 29: 532-533.

38. DiNapoli SR, Hirsch VM, Brenchley JM (2016) Macrophages in Progressive Human Immunodeficiency Virus/Simian Immunodeficiency Virus Infections. J Virol 90: 75967606.

39. Honeycutt JB, Thayer WO, Baker CE, Ribeiro RM, Lada SM, Cao Y, Cleary RA, Hudgens MG, Richman DD, Garcia JV (2017) HIV persistence in tissue macrophages of humanized myeloid-only mice during antiretroviral therapy. Nat Med 23: 638-643. 
40. Murray AJ, Kwon KJ, Farber DL, Siliciano RF (2016) The Latent Reservoir for HIV-1: How Immunologic Memory and Clonal Expansion Contribute to HIV-1 Persistence. J Immunol 197: 407-417.

41. Bruner KM, Hosmane NN, Siliciano RF (2015) Towards an HIV-1 cure: measuring the latent reservoir. Trends Microbiol 23: 192-203.

42. Siliciano JD, Siliciano RF (2013) HIV-1 eradication strategies: design and assessment. Curr Opin HIV AIDS 8: 318-325.

43. Cunyat F, Rainho JN, West B, Swainson L, McCune JM, Stevenson M (2016) ColonyStimulating Factor 1 Receptor Antagonists Sensitize Human Immunodeficiency Virus Type 1-Infected Macrophages to TRAIL-Mediated Killing. J Virol 90: 6255-6262.

44. Xue J, Fu C, Cong Z, Peng L, Peng Z, Chen T, Wang W, Jiang H, Wei Q, Qin C (2017) Galectin3 promotes caspase-independent cell death of HIV-1-infected macrophages. FEBS J 284: 97-113.

45. Busca A, Saxena M, Kryworuchko M, Kumar A (2009) Anti-apoptotic genes in the survival of monocytic cells during infection. Curr Genomics 10: 306-317.

46. Kuo HH, Ahmad R, Lee GQ, Gao C, Chen HR, Ouyang Z, Szucs MJ, Kim D, Tsibris A, Chun TW, Battivelli E, Verdin E, Rosenberg ES, Carr SA, Yu XG, Lichterfeld M (2018) Antiapoptotic Protein BIRC5 Maintains Survival of HIV-1-Infected CD4(+) T Cells. Immunity \%19;48: 1183-1194.

47. Campbell GR, Bruckman RS, Chu YL, Trout RN, Spector SA (2018) SMAC Mimetics Induce Autophagy-Dependent Apoptosis of HIV-1-Infected Resting Memory CD4+ T Cells. Cell Host Microbe 10.

48. Ebert G, Preston S, Allison C, Cooney J, Toe JG, Stutz MD, Ojaimi S, Scott HW, Baschuk N, Nachbur U, Torresi J, Chin R, Colledge D, Li X, Warner N, Revill P, Bowden S, Silke J, Begley CG, Pellegrini M (2015) Cellular inhibitor of apoptosis proteins prevent clearance of hepatitis B virus. Proc Natl Acad Sci U S A 112: 5797-5802.

49. Pache L, Dutra MS, Spivak AM, Marlett JM, Murry JP, Hwang Y, Maestre AM, Manganaro L, Vamos M, Teriete P, Martins LJ, Konig R, Simon V, Bosque A, Fernandez-Sesma A, Cosford ND, Bushman FD, Young JA, Planelles V, Chanda SK (2015) BIRC2/cIAP1 Is a Negative Regulator of HIV-1 Transcription and Can Be Targeted by Smac Mimetics to Promote Reversal of Viral Latency. Cell Host Microbe 18: 345-353.

50. Saxena M, Busca A, Pandey S, Kryworuchko M, Kumar A (2011) CpG protects human monocytic cells against HIV-Vpr-induced apoptosis by cellular inhibitor of apoptosis-2 through the calcium-activated JNK pathway in a TLR9-independent manner. J Immunol 187: 5865-5878.

51. Busca A, Saxena M, Kumar A (2012) Critical role for antiapoptotic Bcl-xL and Mcl-1 in human macrophage survival and cellular IAP1/2 (cIAP1/2) in resistance to HIV-Vpr-induced apoptosis. J Biol Chem 287: 15118-15133. 
52. Saxena M, Busca A, Holcik M, Kumar A (2016) Bacterial DNA Protects Monocytic Cells against HIV-Vpr-Induced Mitochondrial Membrane Depolarization. J Immunol 196: 3754-3767.

53. Dueber EC, Schoeffler AJ, Lingel A, Elliott JM, Fedorova AV, Giannetti AM, Zobel K, Maurer B, Varfolomeev E, Wu P, Wallweber HJ, Hymowitz SG, Deshayes K, Vucic D, Fairbrother WJ (2011) Antagonists induce a conformational change in cIAP1 that promotes autoubiquitination. Science 334: 376-380.

54. Feltham R, Bettjeman B, Budhidarmo R, Mace PD, Shirley S, Condon SM, Chunduru SK, McKinlay MA, Vaux DL, Silke J, Day CL (2011) Smac mimetics activate the E3 ligase activity of cIAP1 protein by promoting RING domain dimerization. J Biol Chem 286: 17015-17028.

55. Busca A, Konarski Y, Gajanayaka N, O'Hara S, Angel J, Kozlowski M, Kumar A (2018) cIAP1/2-TRAF2-SHP-1-Src-MyD88 Complex Regulates Lipopolysaccharide-Induced IL-27 Production through NF-kappaB Activation in Human Macrophages. J Immunol 200: 1593-1606.

56. Khan SZ, Hand N, Zeichner SL (2015) Apoptosis-induced activation of HIV-1 in latently infected cell lines. Retrovirology 12:42. doi: 10.1186/s12977-015-0169-1.: 42-0169.

57. Imbeault M, Lodge R, Ouellet M, Tremblay MJ (2009) Efficient magnetic bead-based separation of HIV-1-infected cells using an improved reporter virus system reveals that p53 upregulation occurs exclusively in the virus-expressing cell population. Virology 393: 160167.

58. Vince JE, Wong WW, Khan N, Feltham R, Chau D, Ahmed AU, Benetatos CA, Chunduru SK, Condon SM, McKinlay M, Brink R, Leverkus M, Tergaonkar V, Schneider P, Callus BA, Koentgen F, Vaux DL, Silke J (2007) IAP antagonists target cIAP1 to induce TNFalphadependent apoptosis. Cell 131: 682-693.

59. Petersen SL, Wang L, Yalcin-Chin A, Li L, Peyton M, Minna J, Harran P, Wang X (2007) Autocrine TNFalpha signaling renders human cancer cells susceptible to Smac-mimeticinduced apoptosis. Cancer Cell 12: 445-456.

60. Probst BL, Liu L, Ramesh V, Li L, Sun H, Minna JD, Wang L (2010) Smac mimetics increase cancer cell response to chemotherapeutics in a TNF-alpha-dependent manner. Cell Death Differ 17: 1645-1654.

61. El-Mesery M, Shaker ME, Elgaml A (2016) The SMAC mimetic BV6 induces cell death and sensitizes different cell lines to TNF-alpha and TRAIL-induced apoptosis. Exp Biol Med (Maywood ) 241: 2015-2022.

62. Bertrand MJ, Doiron K, Labbe K, Korneluk RG, Barker PA, Saleh M (2009) Cellular inhibitors of apoptosis cIAP1 and cIAP2 are required for innate immunity signaling by the pattern recognition receptors NOD1 and NOD2. Immunity 19;30: 789-801.

63. Beug ST, Cheung HH, LaCasse EC, Korneluk RG (2012) Modulation of immune signalling by inhibitors of apoptosis. Trends Immunol 33: 535-545. 
64. Humphries F, Yang S, Wang B, Moynagh PN (2015) RIP kinases: key decision makers in cell death and innate immunity. Cell Death Differ 22: 225-236.

65. Wagner RN, Reed JC, Chanda SK (2015) HIV-1 protease cleaves the serine-threonine kinases RIPK1 and RIPK2. Retrovirology 12:74. doi: 10.1186/s12977-015-0200-6.: 74-0200.

66. Vince JE, Pantaki D, Feltham R, Mace PD, Cordier SM, Schmukle AC, Davidson AJ, Callus BA, Wong WW, Gentle IE, Carter H, Lee EF, Walczak H, Day CL, Vaux DL, Silke J (2009) TRAF2 must bind to cellular inhibitors of apoptosis for tumor necrosis factor (tnf) to efficiently activate nf-\{kappa\}b and to prevent tnf-induced apoptosis. J Biol Chem 284: 35906-35915.

67. Geng J, Ito Y, Shi L, Amin P, Chu J, Ouchida AT, Mookhtiar AK, Zhao H, Xu D, Shan B, Najafov A, Gao G, Akira S, Yuan J (2017) Regulation of RIPK1 activation by TAK1mediated phosphorylation dictates apoptosis and necroptosis. Nat Commun 8: 35900406.

68. Korsmeyer SJ, Wei MC, Saito M, Weiler S, Oh KJ, Schlesinger PH (2000) Pro-apoptotic cascade activates BID, which oligomerizes BAK or BAX into pores that result in the release of cytochrome c. Cell Death Differ 7: 1166-1173.

69. Kim Y, Anderson JL, Lewin SR (2018) Getting the "Kill" into "Shock and Kill": Strategies to Eliminate Latent HIV. Cell Host Microbe 23: 14-26.

70. Berro R, de la Fuente C, Klase Z, Kehn K, Parvin L, Pumfery A, Agbottah E, Vertes A, Nekhai S, Kashanchi F (2007) Identifying the membrane proteome of HIV-1 latently infected cells. J Biol Chem 282: 8207-8218.

71. Muller-Sienerth N, Dietz L, Holtz P, Kapp M, Grigoleit GU, Schmuck C, Wajant H, Siegmund D (2011) SMAC mimetic BV6 induces cell death in monocytes and maturation of monocyte-derived dendritic cells. PLoS One 6: e21556.

72. Gavegnano C, Schinazi RF (2009) Antiretroviral therapy in macrophages: implication for HIV eradication. Antivir Chem Chemother \%19;20: 63-78.

73. Azzam R, Lal L, Goh SL, Kedzierska K, Jaworowski A, Naim E, Cherry CL, Wesselingh SL, Mills J, Crowe SM (2006) Adverse effects of antiretroviral drugs on HIV-1-infected and uninfected human monocyte-derived macrophages. J Acquir Immune Defic Syndr 42: 1928.

74. Koppensteiner H, Banning C, Schneider C, Hohenberg H, Schindler M (2012) Macrophage internal HIV-1 is protected from neutralizing antibodies. J Virol 86: 2826-2836.

75. Tasker C, Subbian S, Gao P, Couret J, Levine C, Ghanny S, Soteropoulos P, Zhao X, Landau N, Lu W, Chang TL (2016) IFN-epsilon protects primary macrophages against HIV infection. JCI Insight 1: e88255.

76. Nitahara-Kasahara Y, Kamata M, Yamamoto T, Zhang X, Miyamoto Y, Muneta K, Iijima S, Yoneda Y, Tsunetsugu-Yokota Y, Aida Y (2007) Novel nuclear import of Vpr promoted 
by importin alpha is crucial for human immunodeficiency virus type 1 replication in macrophages. J Virol 81: 5284-5293.

77. Mukerjee R, Chang JR, Del VL, Bagashev A, Gayed MM, Lyde RB, Hawkins BJ, Brailoiu E, Cohen E, Power C, Azizi SA, Gelman BB, Sawaya BE (2011) Deregulation of microRNAs by HIV-1 Vpr protein leads to the development of neurocognitive disorders. J Biol Chem 286: 34976-34985.

78. Miles MA, Hawkins CJ (2018) Mutagenic assessment of chemotherapy and Smac mimetic drugs in cells with defective DNA damage response pathways. Sci Rep 8: 14421-32517.

79. Sang Y, Miller LC, Blecha F (2015) Macrophage Polarization in Virus-Host Interactions. J Clin Cell Immunol 6: 10-9899.

80. Croft SN, Walker EJ, Ghildyal R (2018) Human Rhinovirus 3C protease cleaves RIPK1, concurrent with caspase 8 activation. Sci Rep 8: 1569-19839.

81. Liao Y, Wang HX, Mao X, Fang H, Wang H, Li Y, Sun Y, Meng C, Tan L, Song C, Qiu X, Ding C (2017) RIP1 is a central signaling protein in regulation of TNF-alpha/TRAIL mediated apoptosis and necroptosis during Newcastle disease virus infection. Oncotarget 8: 4320143217.

82. Rothe M, Pan MG, Henzel WJ, Ayres TM, Goeddel DV (1995) The TNFR2-TRAF signaling complex contains two novel proteins related to baculoviral inhibitor of apoptosis proteins. Cell 83: 1243-1252.

83. Fernandes JR, Berthoud TK, Kumar A, Angel JB (2017) IL-23 signaling in Th17 cells is inhibited by HIV infection and is not restored by HAART: Implications for persistent immune activation. PLoS One 12: e0186823.

84. Busca A, Saxena M, Iqbal S, Angel J, Kumar A (2014) PI3K/Akt regulates survival during differentiation of human macrophages by maintaining NF-kappaB-dependent expression of antiapoptotic Bcl-xL. J Leukoc Biol 96: 1011-1022. 


\section{Figure Legends}

Figure 1. SM induces cell death of $\mathrm{HIV}$-infected myeloid cells. (A) U937 (n=9) and chronically infected counterpart U1 cells $(n=10)$ were treated with SM-LCL161 at 1, 2, and 4 $\mu \mathrm{M}$ for 48 hr. (B) PMA differentiated U937 $(n=7)$ and U1 cells $(n=11)$ were treated with SM LCL161 at 1, 2, and $4 \mu \mathrm{M}$ for $48 \mathrm{hr}$. Cell death was assessed by intracellular PI staining. The pvalues were calculated using Mann-Whitney U test. $\left({ }^{* * *} \mathrm{p}=<0.0001,{ }^{* *} \mathrm{p}=0.002\right)$. (C) U937 and U1 were treated with increasing concentration of SM-LCL161 for $48 \mathrm{hr}$ and cytosolic fractions were collected and subjected to Western immunoblotting. $30 \mu \mathrm{g}$ of total proteins were loaded to the protein gels. The membranes were probed with antibodies specific for caspase-3. The figure shown is a representative of three experiments.

Figure 2. SM induces cell death of HIV-infected MDMs (A). The HIV-infected MDMs were treated with increasing concentration of SM-LCL161 for $48 \mathrm{hr}$. The cytosolic fractions were subjected to Western immunoblotting. The membranes were probed with antibodies specific for human cIAP-1 and cIAP-2. (B) Human MDMs were in vitro infected with HIV-cs204 (100 ng p24 / well) for 7 days. The cells were then treated with SM-LCL161 for $48 \mathrm{hr}$ and cell death was assessed by PI staining and flow cytometry. The representative histograms are shown in (C). (D) After 7-days of infection, supernatants were analyzed for p24 by ELISA. (E) MDMs generated from naïve and ART-treated HIV-individuals were treated with SM-LCL161 for $48 \mathrm{hr}$. Cell death was assessed by PI staining and flow cytometry. Supernatants from SM-treated in vitro HIV-infected MDMs (F) and SM treated U1 cells (G) were analyzed for p24 secretion. The pvalues were calculated using Mann-Whitney U test. 
Figure 3. SM specifically induces cell death of HIV-HSA-infected MDMs. (A) Gating strategy for the detection of apoptosis of HIV infected total (HSA+ and HSA- ) MDMs, and high HSA-expressing MDMs. (B) MDMs were in vitro infected with HIV-Bal-HSA for 9 days. Cells were treated with DMSO or 5 $\mu$ M AEG40730 for 72 hr. Cell death of total HIV-HSA+ and HIVHSA- MDMs was detected by Annexin-V-BV711 and flow cytometry (left panel). Representative histogram shows HIV-HSA-infected cells (middle panel) and cell death of total HSA+ and HSA- HIV-infected cells (right panel). (C) Intensely HSA positive HIV-infected cells were gated and analyzed for apoptosis by Annexin-V-BV711 staining and flow cytometry (left panel). Representative histogram shows intensely positive HIV-HSA-infected cells (middle panel) and cell death of high HSA+ cells (right panel). The p values in B and C were calculated using Mann-Whitney U test. (D) SM specifically kill HIV-HSA-infected cells but not HIV-HSAMDM. MDMs were infected with HIV-HAS for 11 days followed by treatment with either SMLCL-161 (upper panel) or AEG40730 (lower panel) for another two hr followed by analysis of cell death by PI staining ( $\mathrm{n}=5)$. The $\mathrm{p}$-values were calculated using paired t test.

Figure 4. SM specifically induces cell death of HIV-GFP-infected MDMs. (A) Gating strategy for the detection of apoptosis of total HIV-eGFP infected and specific high HIV-GFP expressing MDMs. (B) MDMs were in vitro infected with HIV-eGFP for 7 days. Cells were treated with DMSO or AEG40730 for 72 hr. The cell death of the total population of HIV-GFPinfected MDMs was detected by Annexin-V-BV711 and flowcytometry (left panel). Representative histogram shows HIV-GFP-infected cells (middle panel) and cell death of total GFP+ and GFP- HIV-infected cells (right panel). (C) Intensely GFP-positive HIV-infected cells 
were gated and analyzed for apoptosis by Annexin-V-BV711 staining and flow cytometry (left panel). Representative histogram showing intensely positive HIV-GFP-infected cells (middle panel) and cell death of high GFP+ cells (right panel). p-values were calculated using Mann Whitney U test $(\mathrm{n}=4)$.

Figure 5. IAP siRNA specifically induces cell death of HIV-HSA-infected MDMs. (A) Gating strategy for the detection of apoptosis of total HIV-HSA infected MDMs, HSAexpressing MDMs, and specific apoptosis of HIV-HSA infected MDMs. (B) MDMs were in vitro infected with HIVNL4.3-Bal-HSA for 9 days. The cells were transfected with non-targeting control siRNA or cIAP1/2 siRNA. After 72 hr of transfection, cell death of the total population of HIV-HSA-infected MDMs was detected by Annexin-V-BV711 and flow cytometry (left panel). Representative histogram showing HIV-HSA-infected cells (middle panel) and cell death of total (HSA+ and HSA- ) HIV-infected cells (right panel). (C) Intensely HIV-HSA positive HIV-infected cells were gated and analyzed for apoptosis by Annexin-V-BV711 staining and flow cytometry (left panel). Representative histogram showing intensely positive HIV-HSAinfected cells (middle panel) and cell death of high HSA+ cells (right panel). p-values were calculated using Mann Whitney U test ( $\mathrm{n}=4)$.

Figure 6. SM-induced cell death of HIV-infected MDMs is mediated by apoptosis. In vitro HIV-infected MDM were treated with SM-LCL161 for $48 \mathrm{hr}$. The cells were treated with Z-Vad pan-caspase inhibitor for $2 \mathrm{hr}$ prior to SM-LCL-161 (3 $\mu \mathrm{M})$. The activation of caspases was detected by fluorescent caspase substrate (caspase-3, $n=3$; caspase- 8 , $n=4$; caspase-9, $n=6$ ). The p values were calculated using Mann-Whitney U test. 
Figure 7. TNF- $\alpha$ mediates SM-induced apoptosis in U1 cells but not in primary HIVinfected MDM

SM induced cell death in U1 cells is regulated by $\mathrm{r}$ TNF-a. SM induce TNF $\alpha$ secretion in undifferentiated and differentiated U937 and U1 cells (A-D). Undifferentiated U 937 (A), undifferentiated U1 (B), differentiated U937 (C) and differentiated U1 (D) cells were treated with various concentrations of SM-LCL161 for $48 \mathrm{hr}$. The supernatants were analyzed for TNF$\alpha$ production by ELISA.

SM treatment of HIV-infected MDMs does not induce TNF $\alpha$ production. (E). Human MDMs were in vitro infected with HIV-cs204 (100 ng p24 / well) for 7 days followed by the addition of SM-LCL161 for $48 \mathrm{hr}(\mathrm{n}=3)$. (F) MDMs derived from HIV-patients were treated with SMLCL161 for $48 \mathrm{hr}(\mathrm{n}=4)$. Supernatants were analyzed for TNF $\alpha$ production by ELISA. U 937 (G) and U1 (H) were treated with either SM-LCL161 alone, rTNF- $\alpha$ alone or with SM-LCL161 and various concentrations of rTNF- $\alpha$ for $48 \mathrm{hr}$ followed by analysis of cell death by PI staining and flow cytometry. (I) MDMs were treated with SM-LCL161 for 2 hr followed by the addition of rTNF- $\alpha$ for $48 \mathrm{hr}$. Intracellular PI staining and flow cytometry were used to assessed levels of cell death (n=3). p-values were calculated using paired t test or Mann-Whitney U test.

Figure 8. HIV infection results in downregulation of RIPK1 in MDMs. (A) Human MDMs were in vitro infected with HIV-cs204 (100 ng p24 / well) for 7 days followed by the addition of SM-LCL161 for 48 hr. (B) Human MDMs were in vitro infected with HIV-cS204 (100 ng p24 / well) and cells were harvested on day $0,2,4,6$, and 8. Cell lysates were subjected to Western 
immunoblotting for RIPK-1. The results shown are representative of 4 experiments (A) and twice for B. (C) Gating strategy for detection of HIV-HSA infected macrophages. HIV-infected bulk MDMs were gated as singlets followed by staining for live cells using E450 live/dead staining kit (Invitrogen). HIV-HSA-infected cells were detected within the live cell population by using FITC-labelled anti-CD24 antibodies (left panel). MDM were in vitro infected with R5 tropic HIV-Bal-HSA as above for 11 days following which cells were subjected to magnetic column separation using CD-24 (HSA)-biotin conjugated antibodies. The \% of HIV-HSAinfected MDM in isolated unsorted, negative, waste and positive fractions as assessed by flow cytometry is shown (right panel). (D) Isolated fractions of HIV-HSA, namely negative fraction (negative sort), waste fraction and positively isolated fraction (positive sort) were subjected to Western immunoblotting for analysis of RIPK-1 and pRIPK-1. (E). Human MDMs were in vitro infected with HIV-cs204 (100 ng p24 / well) for 7 days followed by the addition of SM-LCL161 for 48 hr. Cell lysates were analyzed for TRAF-1, TRAF-2, Bid and Bax by Western immunoblotting. The results shown are a representative of two (upper panel) and 4 (lower panel) experiments respectively.

Figure 9. Concomitant downregulation of cIAP1/2 and RIPK-1 in MDMs derived from healthy donors results in activation of apoptosis. (A) MDMs were treated with $10 \mu \mathrm{M}$ necrostatin-1 for $2 \mathrm{hr}$ followed by the addition of increasing concentration of SM- LCL161 for 48 hr. Cell death was assessed by intracellular PI staining and flow cytometry. p-values were calculated using Mann-Whitney U test $(n=4)$. (B) Representative histograms of the four experiments is shown. (C) MDMs treated as above with necrostatin-1 and SM-LCL161 were 
bioRxiv preprint doi: https://doi.org/10.1101/543017; this version posted February 6,2019 . The copyright holder for this preprint (which was not certified by peer review) is the author/funder, who has granted bioRxiv a license to display the preprint in perpetuity. It is made available under aCC-BY 4.0 International license.

harvested and subjected to Western immunoblotting for caspase-3, -8, -and 9, PARP, and betaactin. The blots shown is a representative of three experiments. 


\section{Online supporting information}

Supp Fig 1. SM induce the activation of caspases in HIV-infected MDMs. Human MDMs were in vitro infected with HIV-cs204 (100 ng p24 / well) for 7 days. The cells were then treated with SM-LCL161 for $48 \mathrm{hr}$. The activation of the caspase-3, 8, and 9 were detected by intracellular caspases staining and flow cytometry. Representative histograms are shown.

Supp Fig 2. SMs induce cell death in M1 macrophages. (A). M0 and M1 MDMs were treated with increasing concentration of SM-LCL161 $48 \mathrm{hr}(\mathrm{n}=3)$. Cell death was assessed by intracellular PI staining and flow cytometry. The p-values were calculated using Mann-Whitney U test. (B) A representative histograms for cell death in M1 macrophages is shown.

Suppl. Fig 3. HIV infection of MDMs does not result in the upregulation of cytokines related to M1 phenotype. MDMs were in vitro infected with mock or $\mathrm{HIV}_{\mathrm{CS} 204}$. The supernatants collected after 7 days of infection were analyzed for the secretion of cytokines using Human Th17 magnetic panel cytokine array kit for 22 different cytokines $(n=6)$. The p-values were calculated using Mann-Whitney U test

Supp Fig 4. SM does not induce aberrant production of M1 cytokines in mock and HIVinfected MDMs. The in vitro mock and HIVcs204-infected MDM for 7 days were treated with SM LCL161 for $48 \mathrm{hr}$. Supernatants were collected, and cytokine profile was analyzed through Human Th17 magnetic panel cytokine array kit $(n=3)$

Supp 5. Supp Fig 6. SM does not induce cytokine production in MDMs generated from HIV-infected individuals. PBMC from ART-treated HIV+ patients were differentiated into macrophages for 7-days and subsequently treated with SM LCL161 for $48 \mathrm{hr}$. The supernatants were analyzed for cytokines through Human Th17 magnetic panel cytokine array. P-values were calculated using paired-T test $(\mathrm{n}=3)$ 
bioRxiv preprint doi: httos://doi.org/10 1101/543017: this version posted Februarv 6 2019. The copvriaht holder for this preprint (which was not certified by peer review) is the author/funder, who has granted bioRxiv a license to display the preprint in perpetuity. It is made available under aCC-BY 4.0 International license. 
A

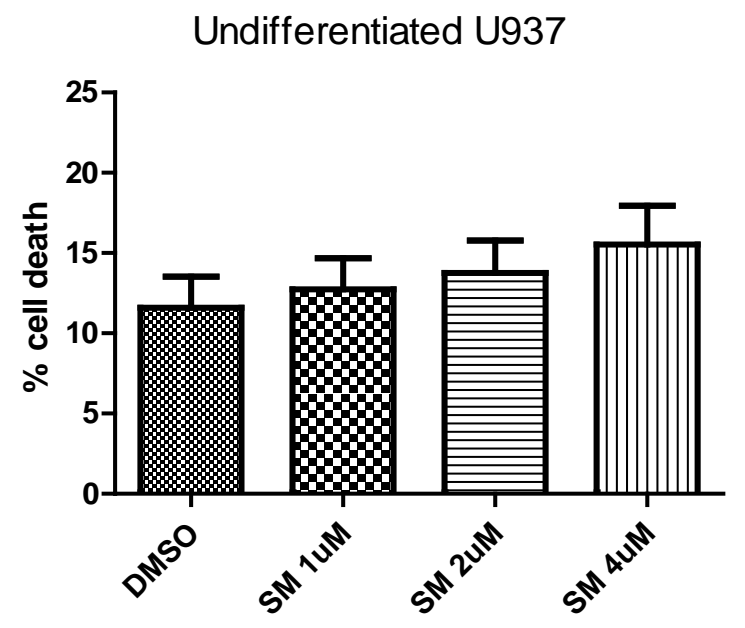

B

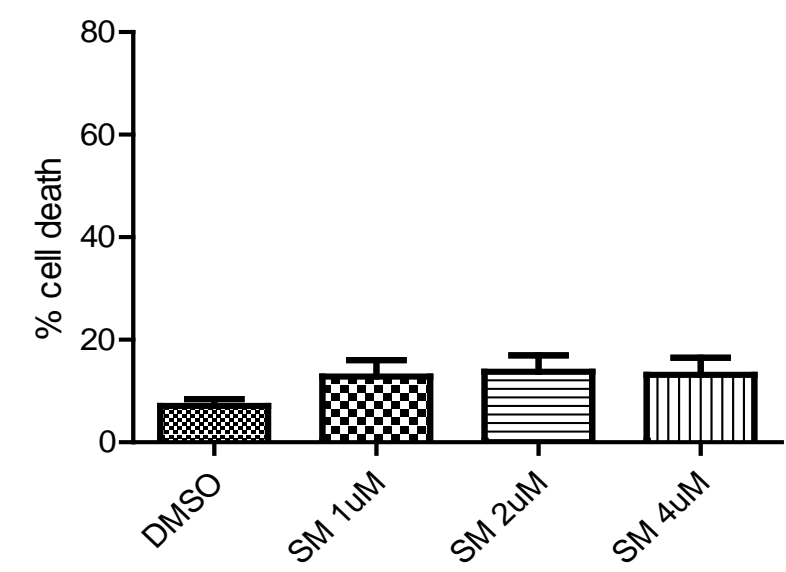

C

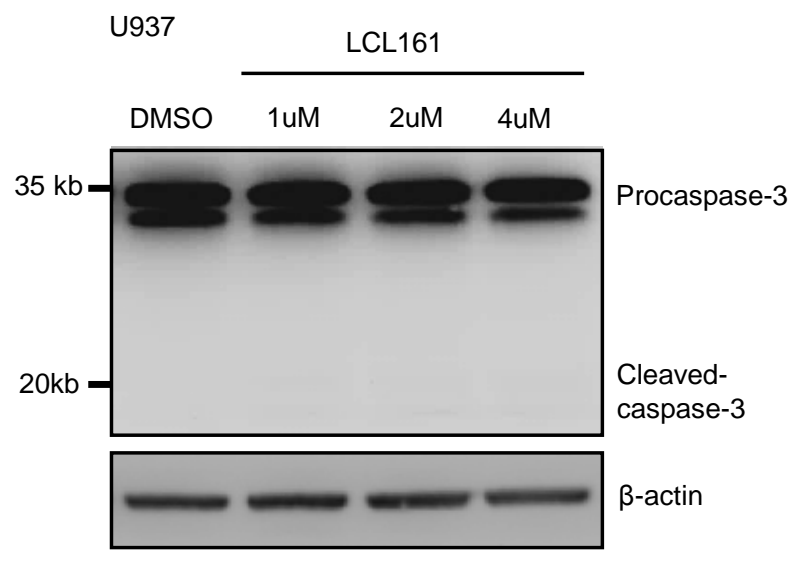

Undifferentiated U1

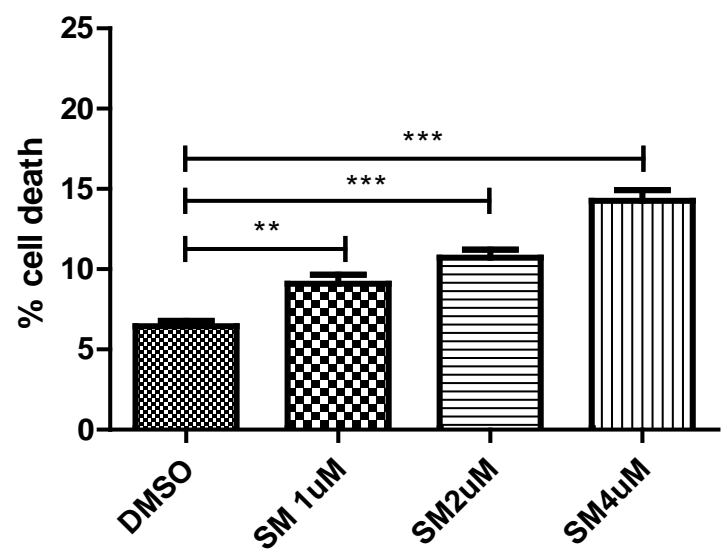

Differentiated U1
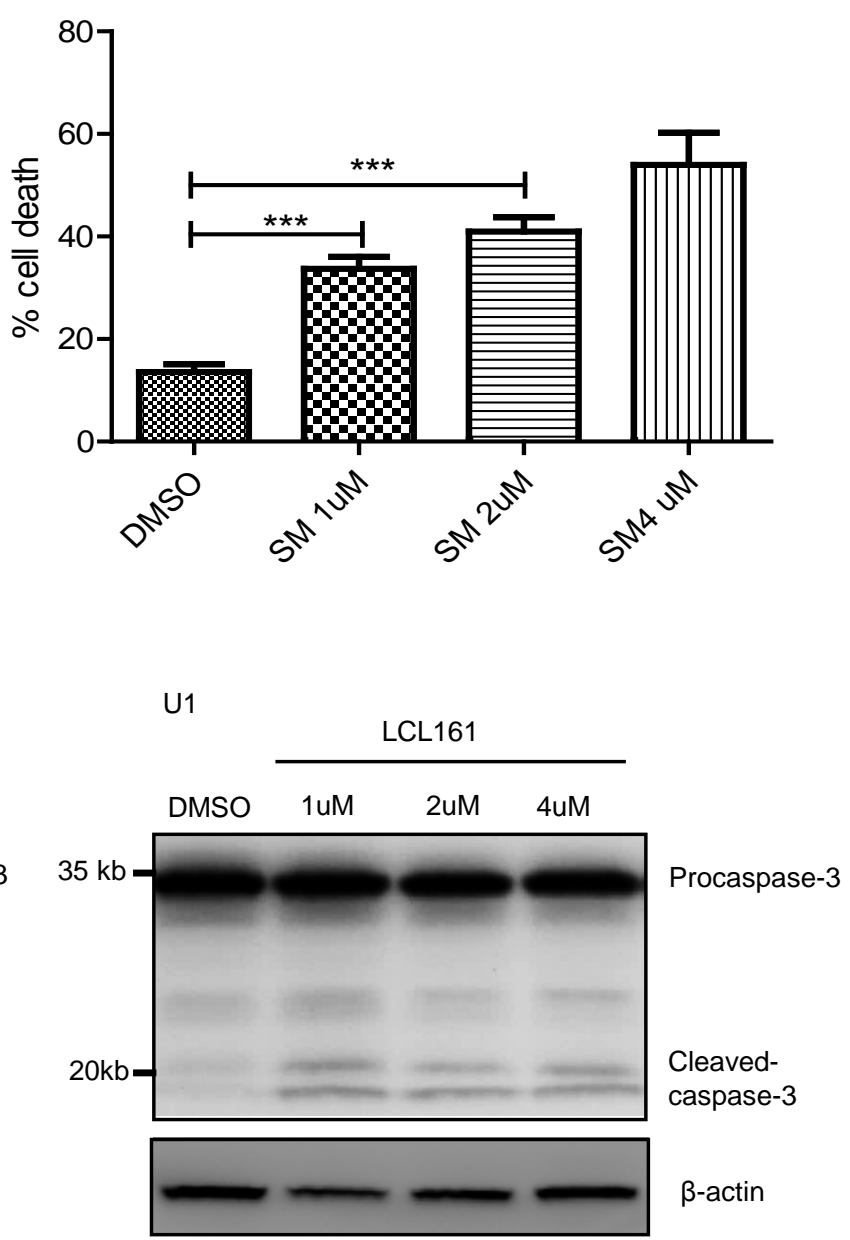
bioRxiv preprint doi: https://doi.org/10.1101/543017; this version posted February 6,2019 . The copyright holder for this preprint (which was not certified by peer review) is the author/funder, who has granted bioRxiv a license to display the preprint in perpetuity. It is made available under aCC-BY 4.0 International license.

A

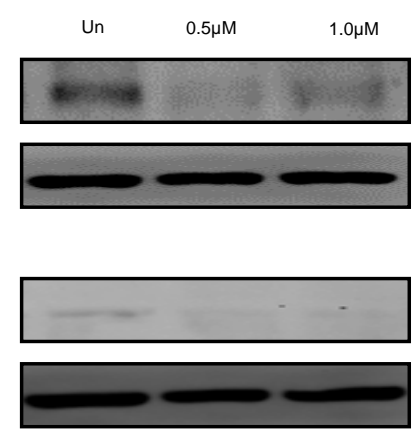

CIAP2

$\beta$-actin

CIAP1

$\beta$-actin
B

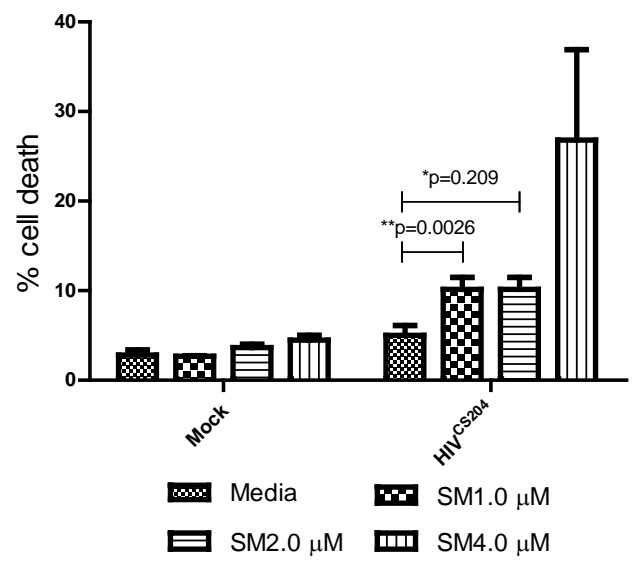

C

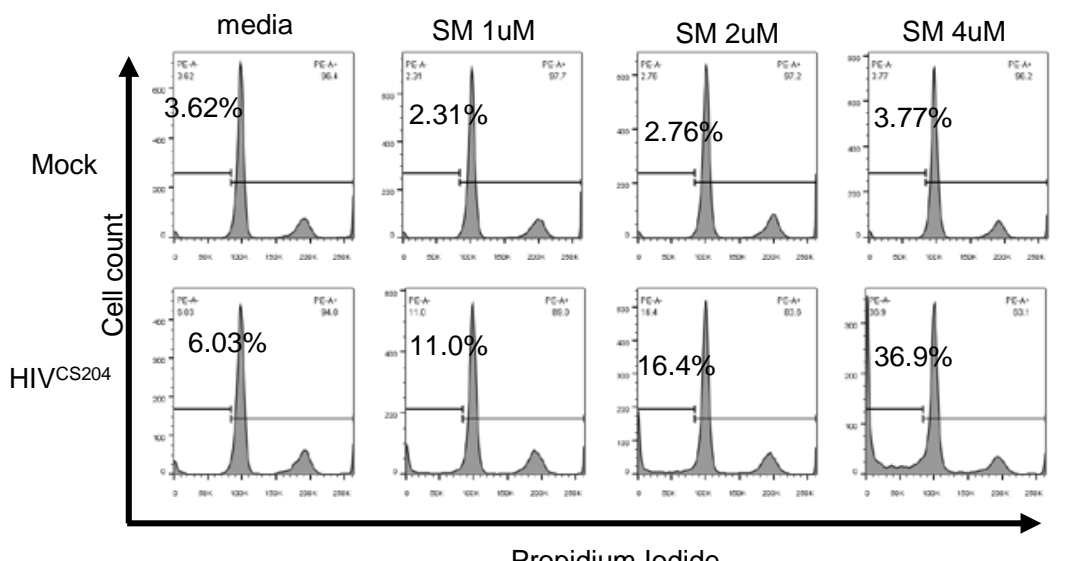

Propidium lodide

$\mathrm{E}$

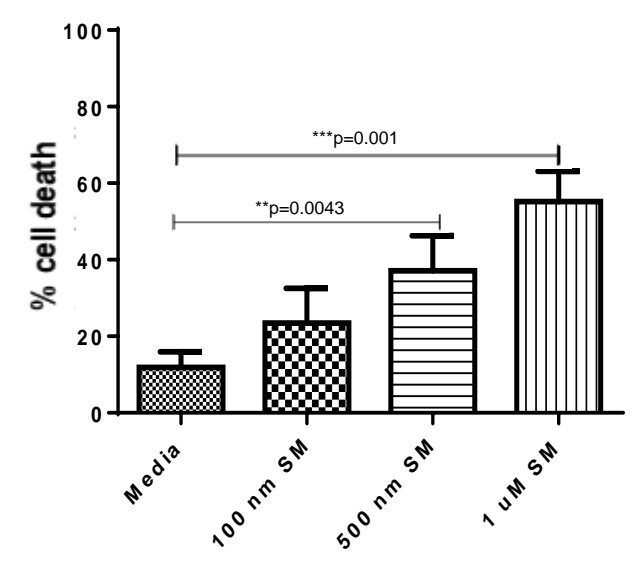

$\mathrm{F}$

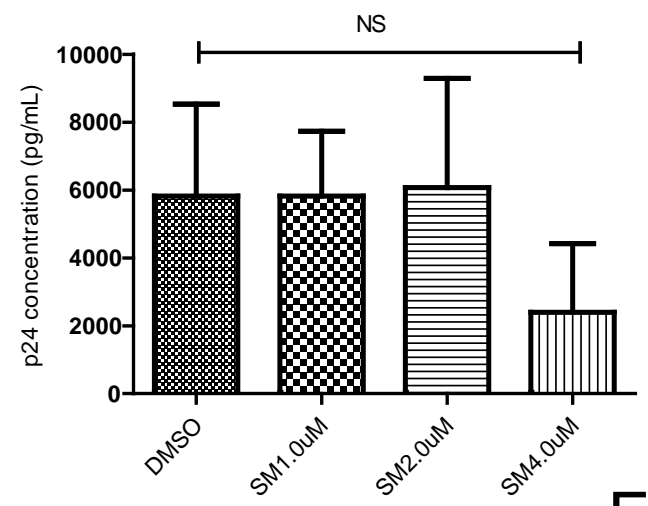

D

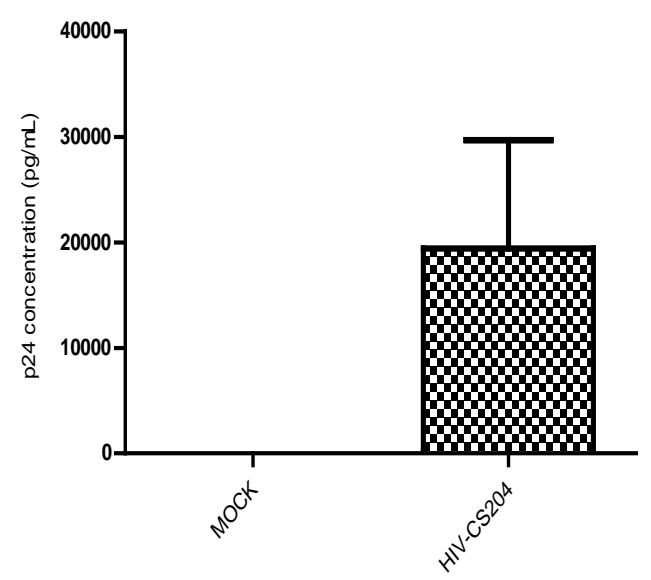

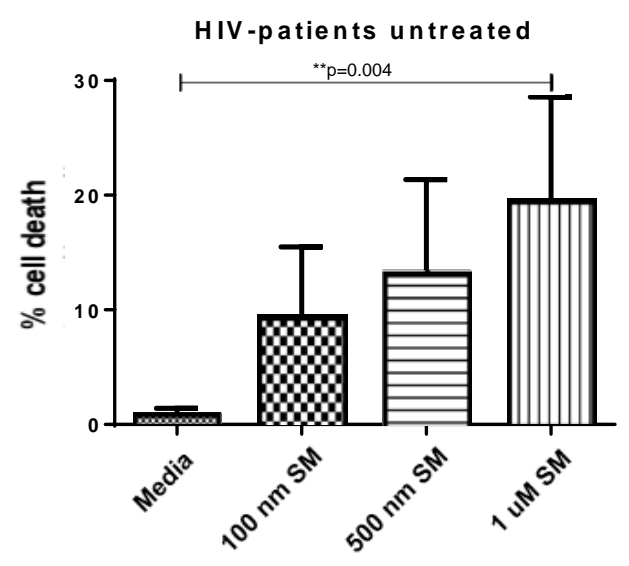

G

U1

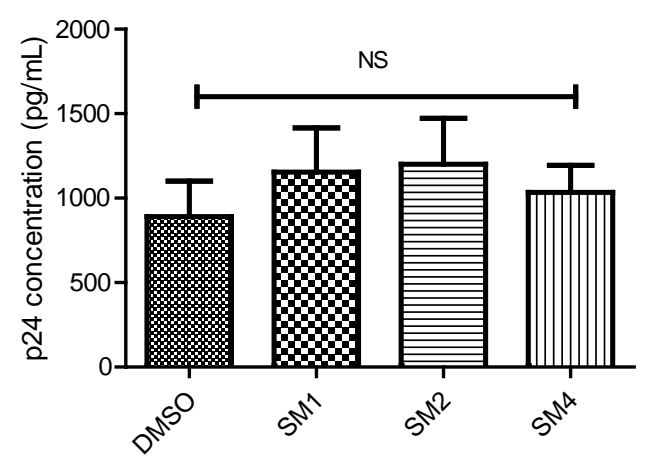

Figure 2 
bioRxiv preprint doi: https://doi.org/10.1101/543017; this version posted February 6, 2019. The copyright holder for this preprint (which was not certified by peer review) is the author/funder, who has granted bioRxiv a license to display the preprint in perpetuity. It is made available under

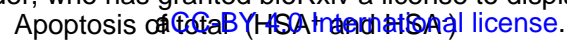

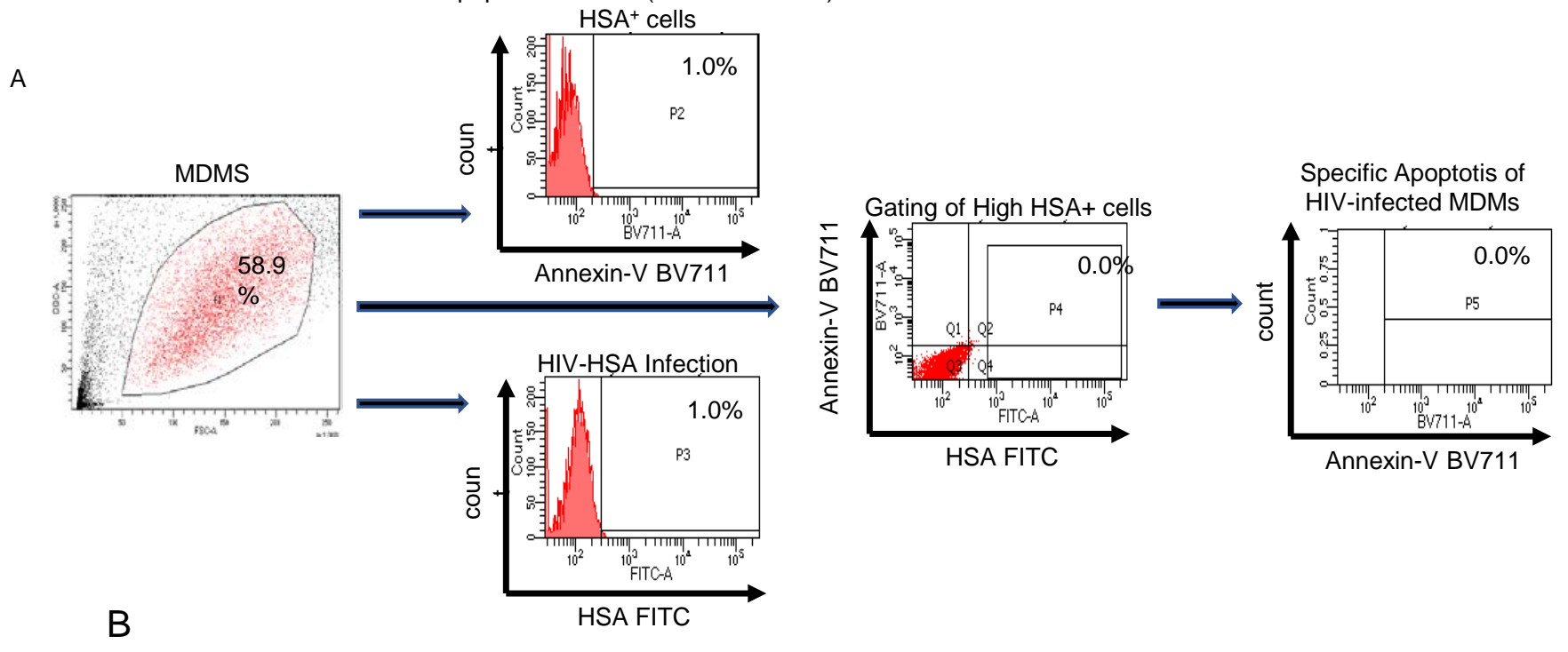

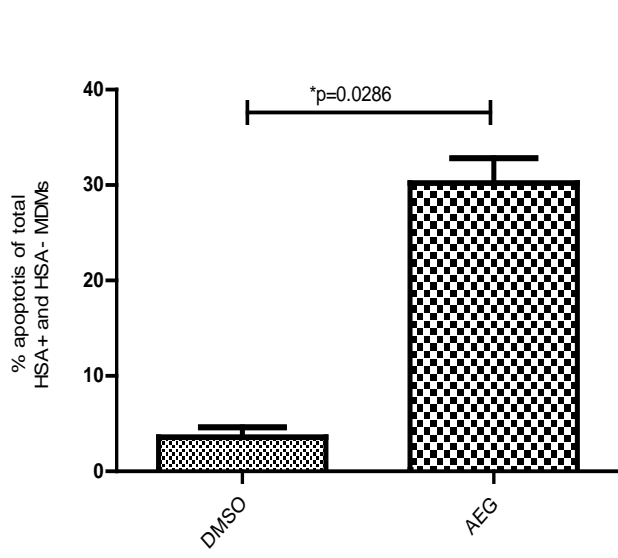

in vitro HIV-HSA infected

C

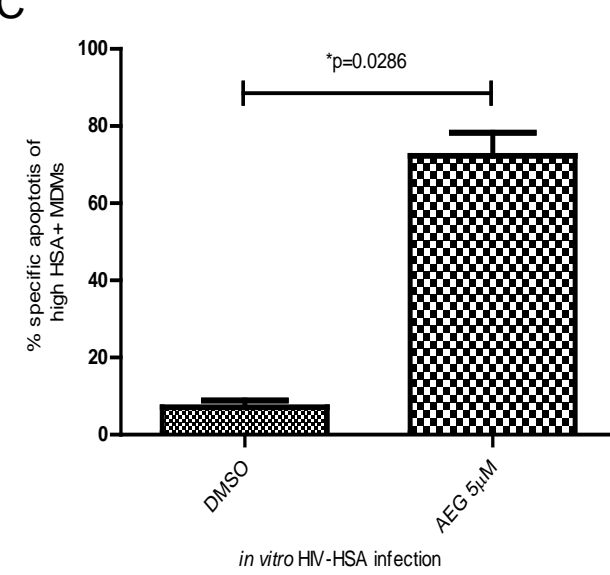

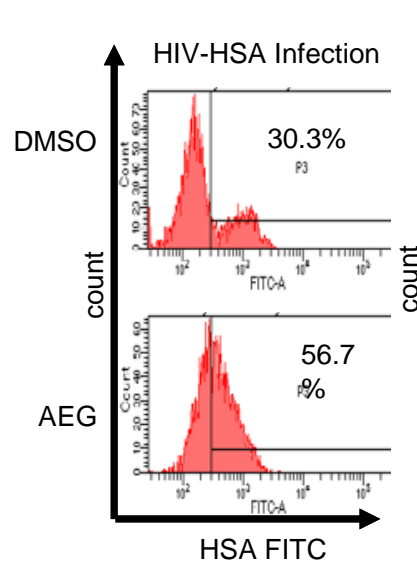

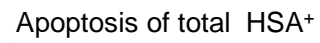
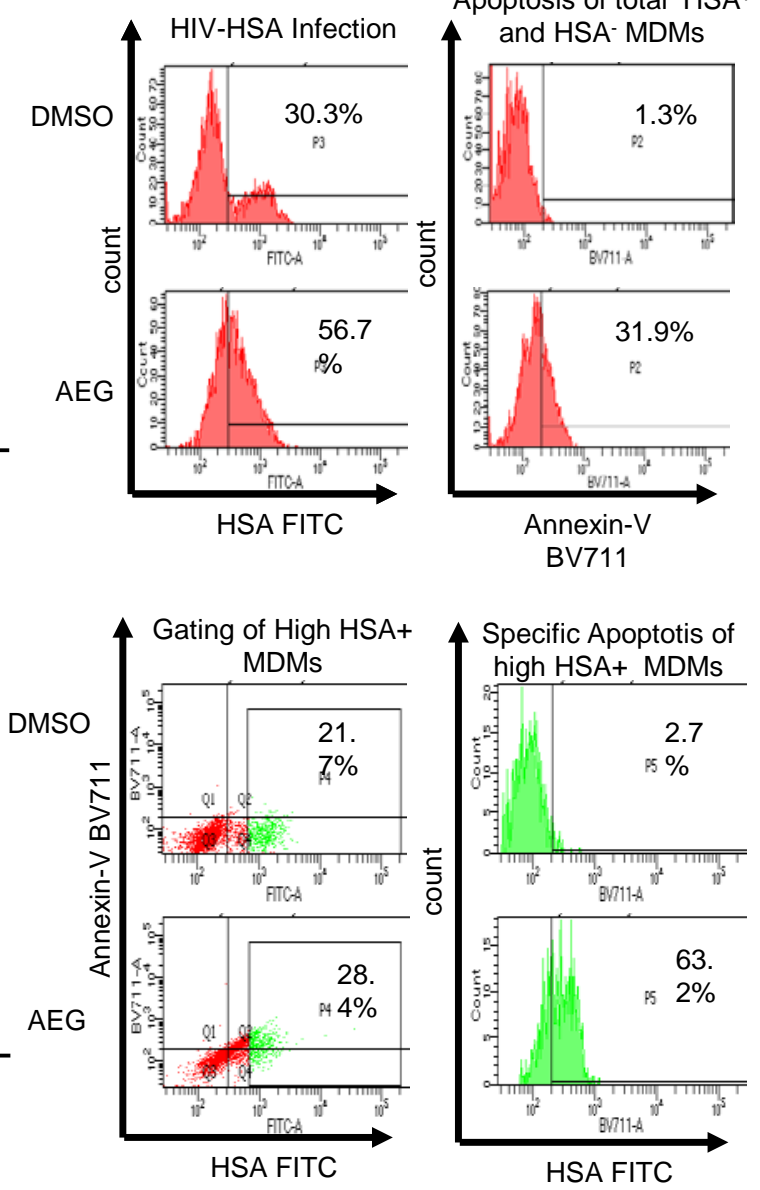

D
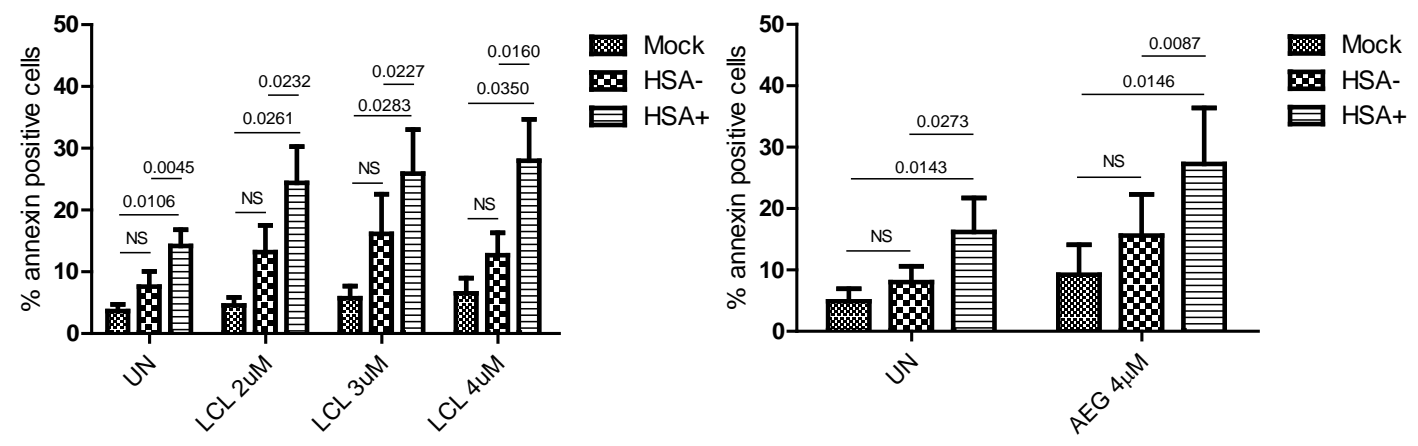

Figure 3 
bioRxiv preprint doi: https://doi.org/10.1101/543017; this version posted February 6, 2019. The copyright holder for this preprint (which was not certified by peer review) is the author/funder, who has granted bioRxiv a license to display the preprint in perpetuity. It is made available under aCC-BY 4.0 International license.
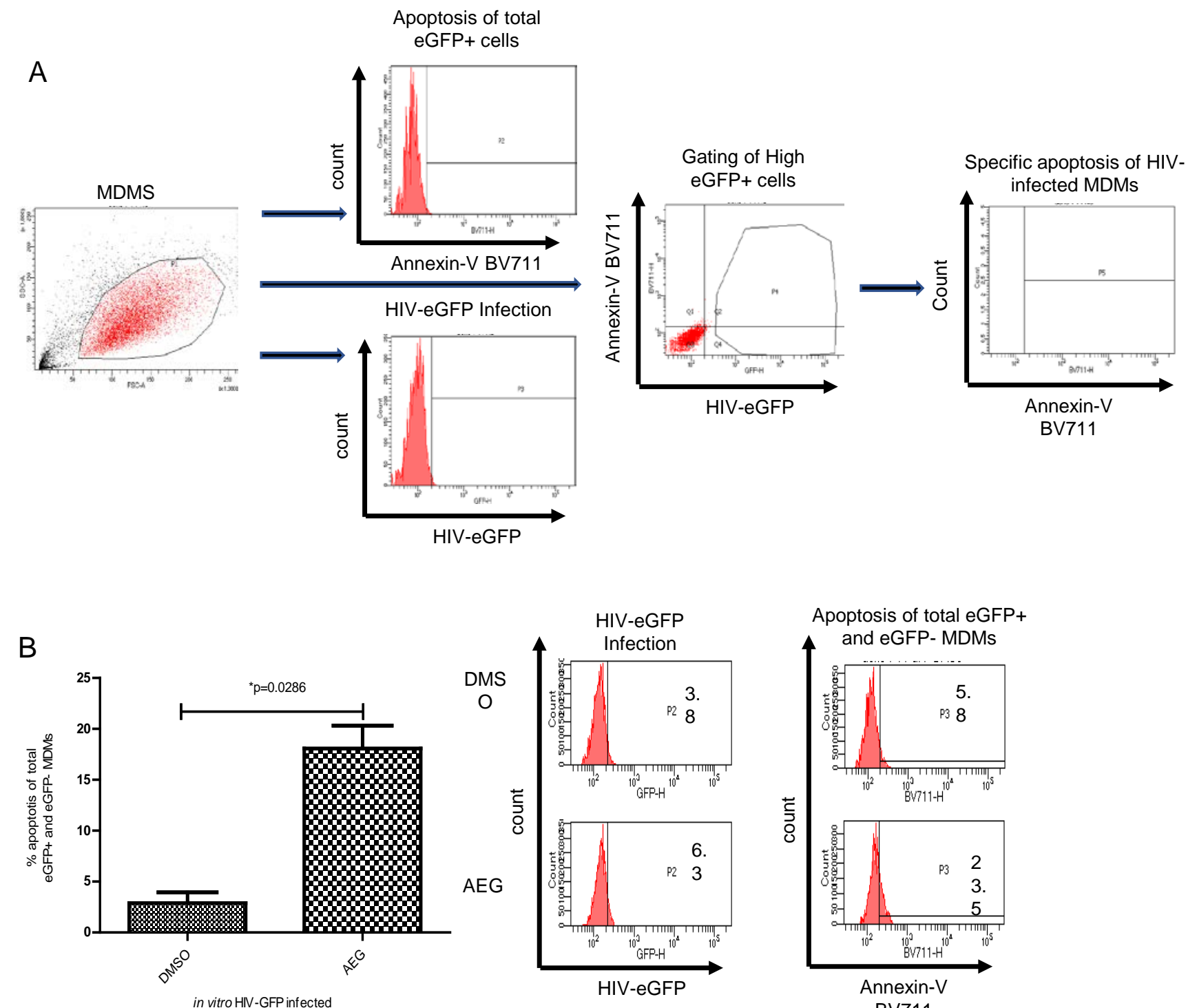

C
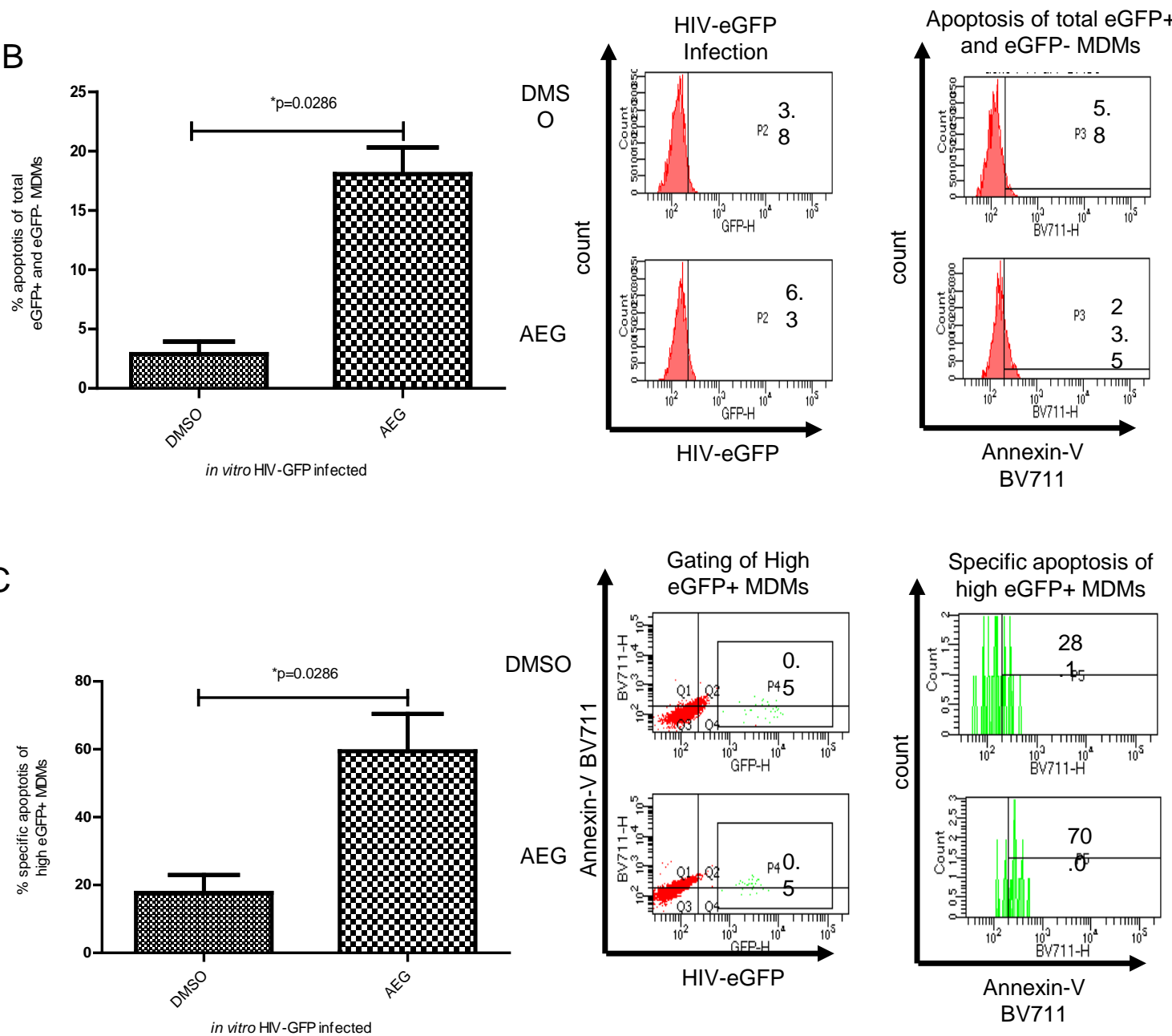

Figure 4. 
bioRxiv preprint doi: https://doi.org/10.1101/543017; this version posted February 6, 2019. The copyright holder for this preprint (which was not certified by peer review) is the author/funder, who has granted bioRxiv a license to display the preprint in perpetuity. It is made available under

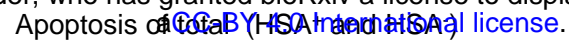
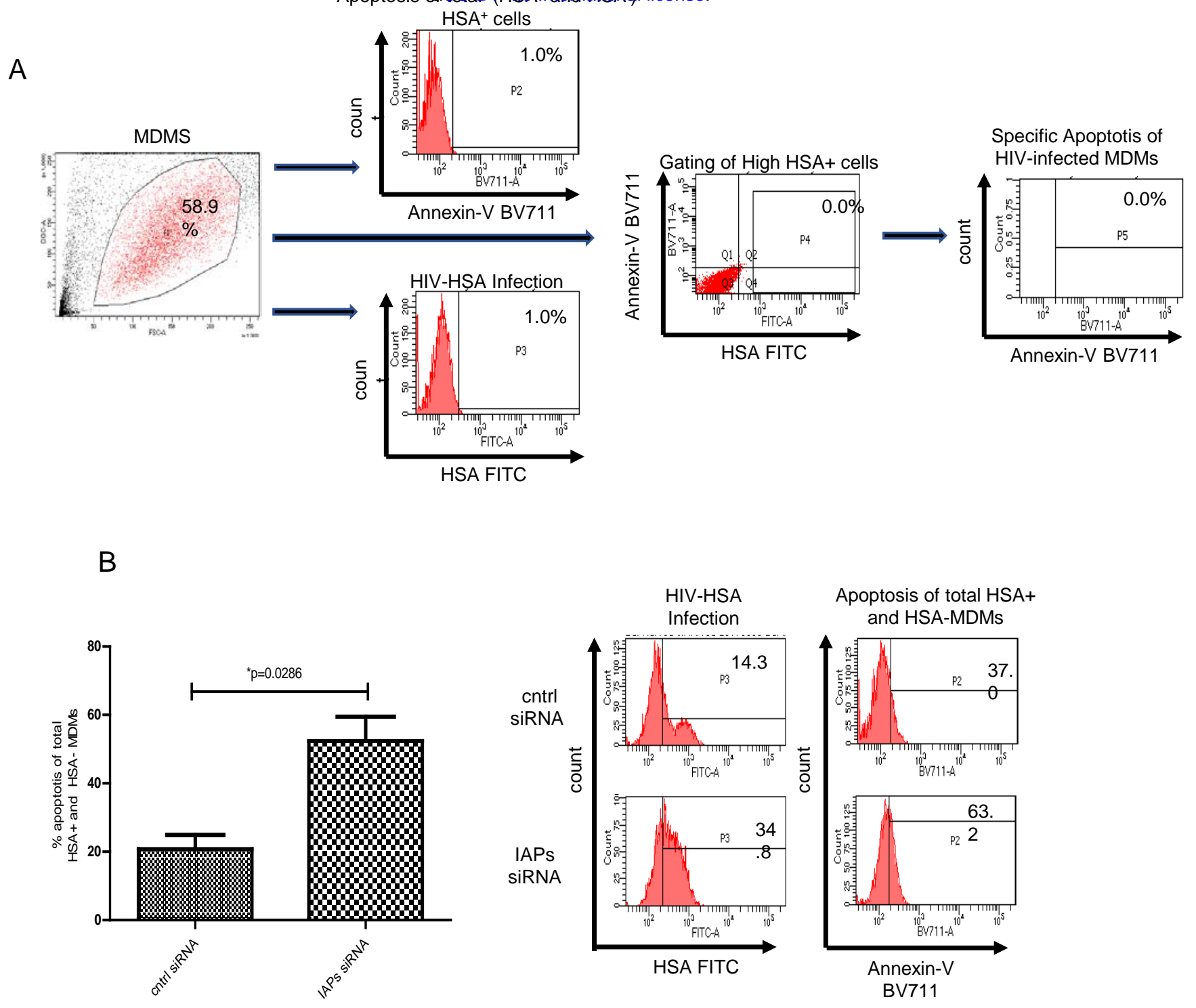

in vitro HIV-HSA infected
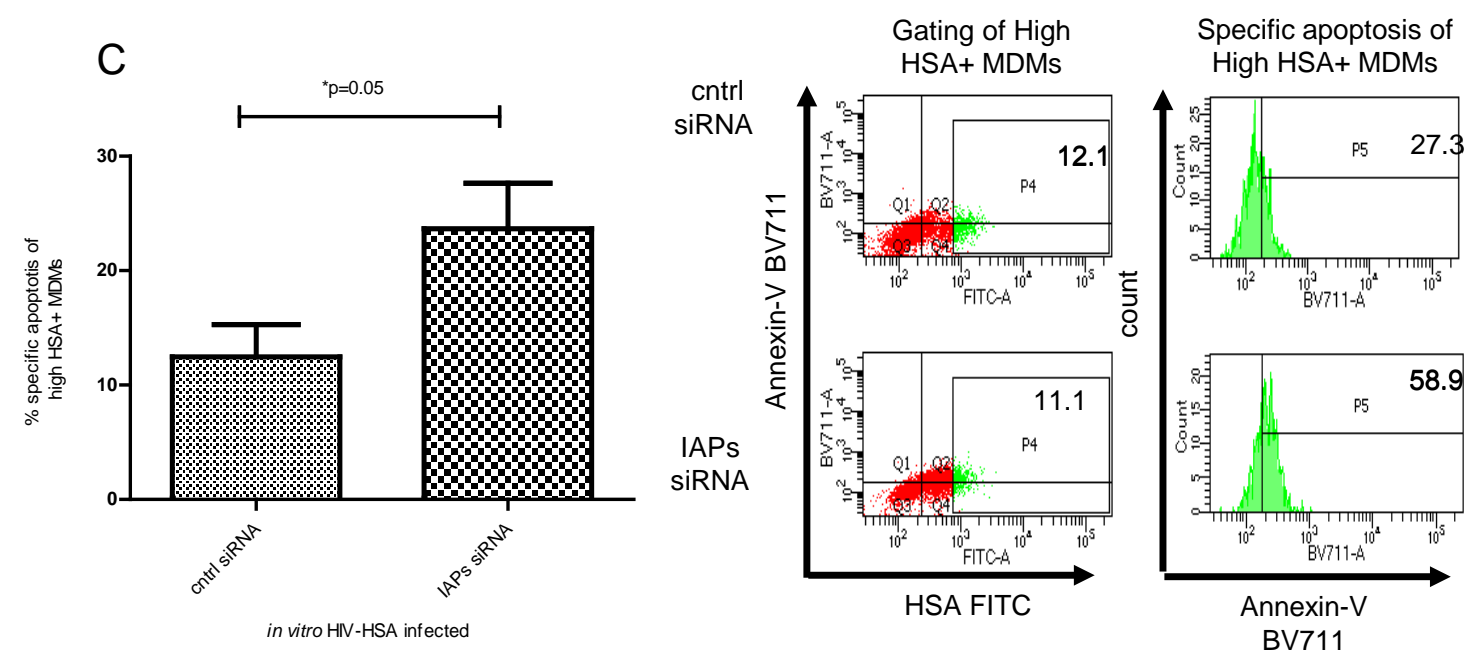

Figure 5 
Mock-infected

caspase-3
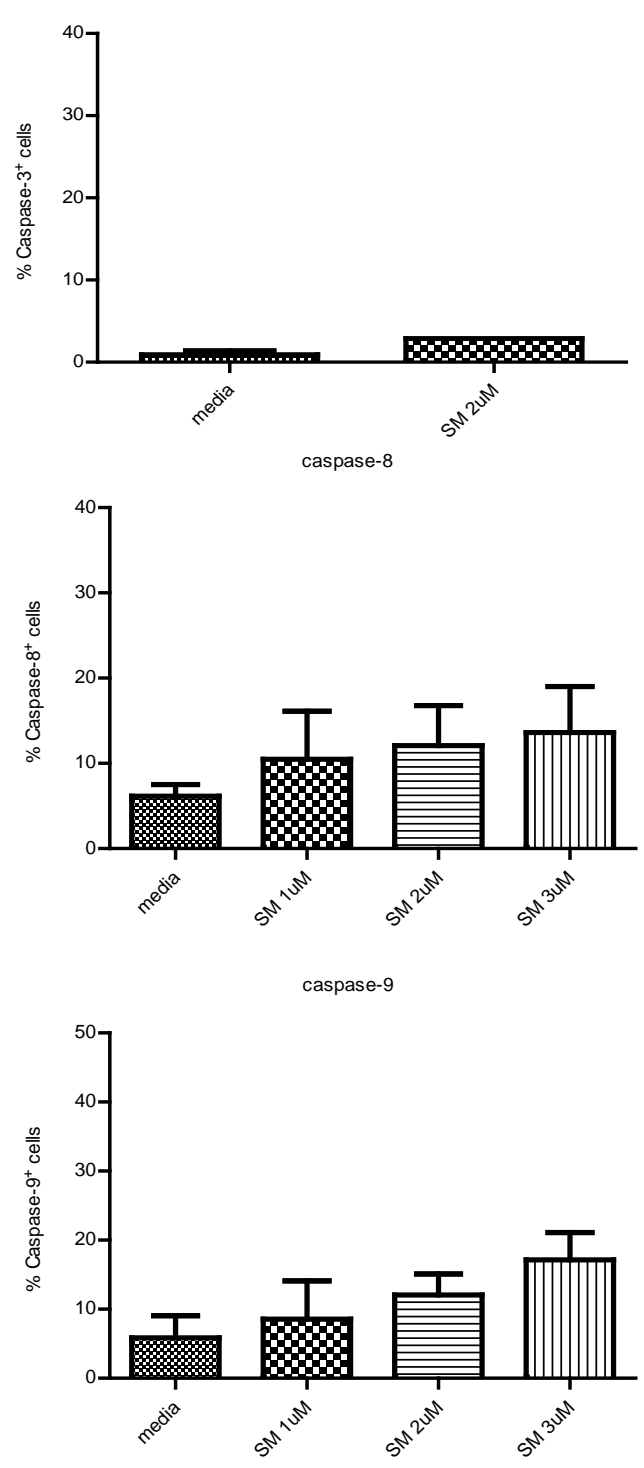

HIV-cs204-infected
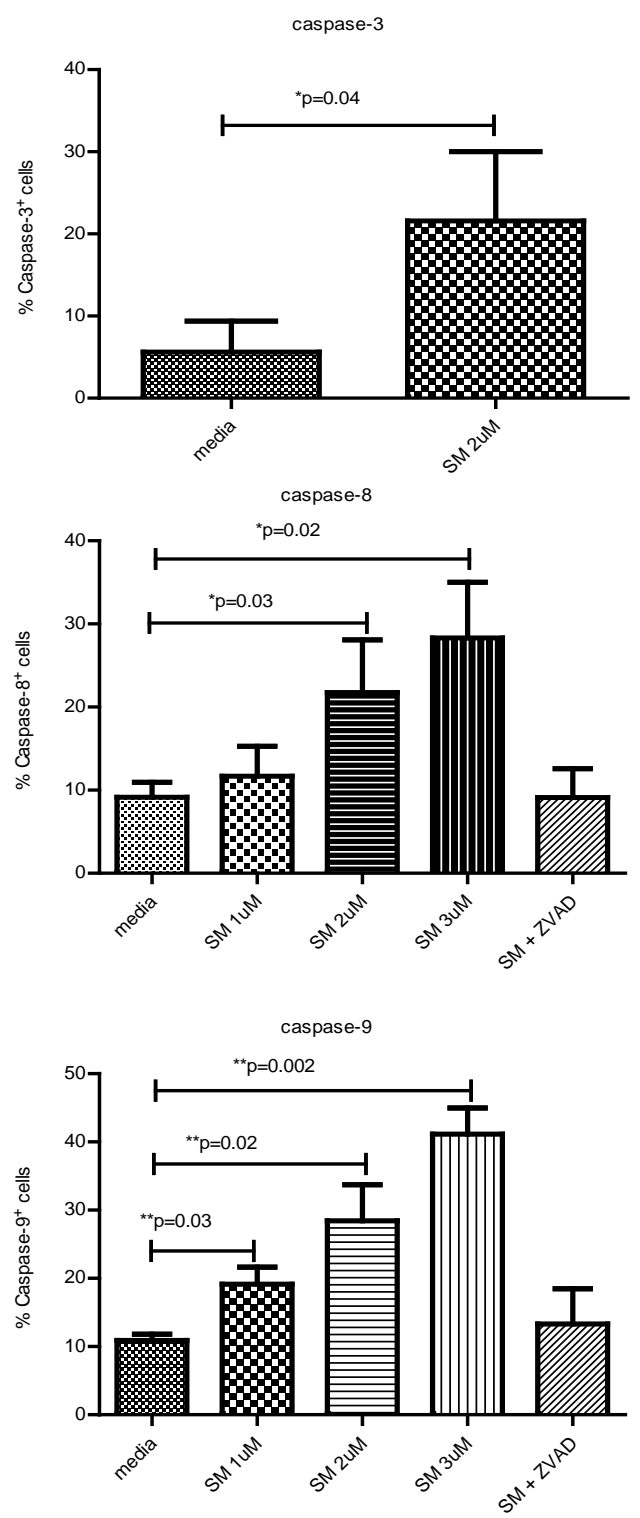

Figure 6 
bioRxiv preprint doi: https://doi.org/10.1101/543017; this version posted February 6, 2019. The copyright holder for this preprint (which was not certified by peer review) is the author/funder, who has granted bioRxiv a license to display the preprint in perpetuity. It is made available under

A aCC-BY 4.0 Internationgl license. undifferentiated U1

undifferentiated U937
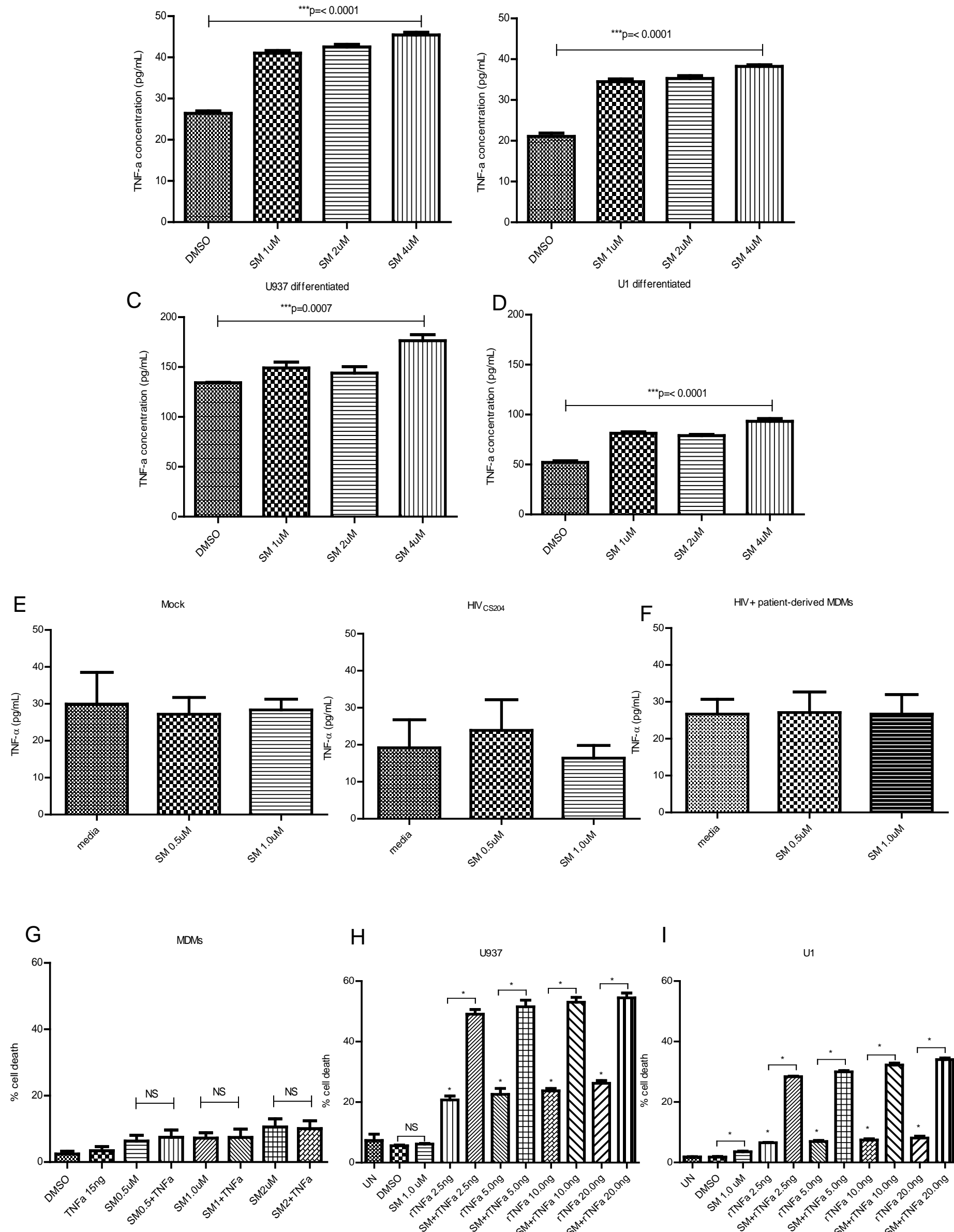

$\mathrm{H}$

U937

I
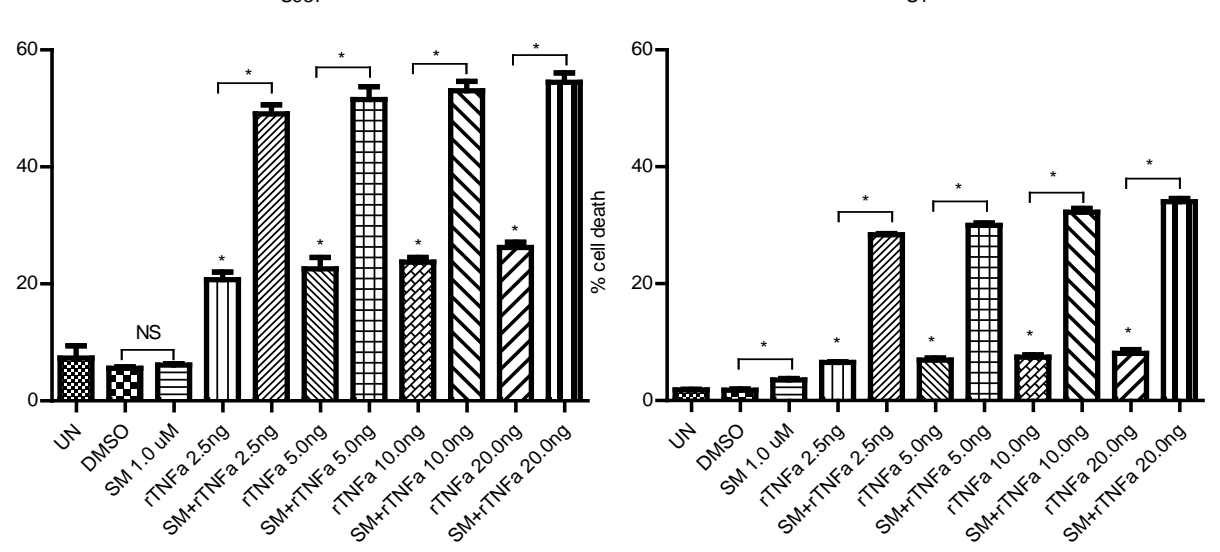

Figure 7 
bioRxiv preprint doi: $h$ ttps://doi.org/101101/543017; this version posted February 6, 2019. The copyright holder for this preprint (which was not certified by peer review) is the author/funder, who has granted bioRxiv a license to display the preprint in perpetuity. It is made available under aCC-BY 4.0 International license.

A
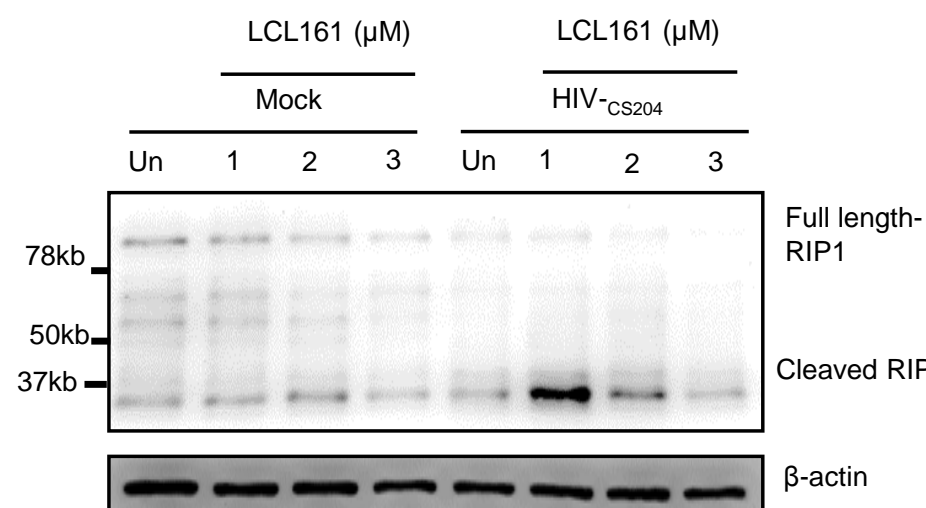

C

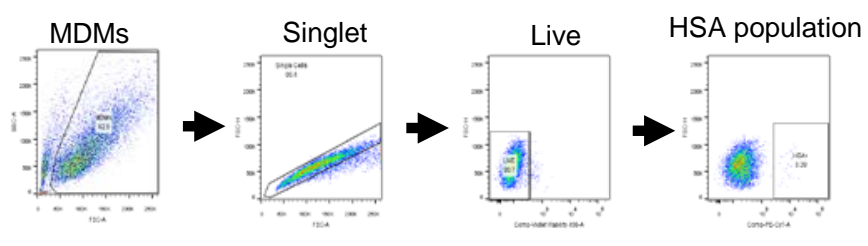

HIV-HSA

Mock infected negative fraction CD-24 stained

CD-24 stained
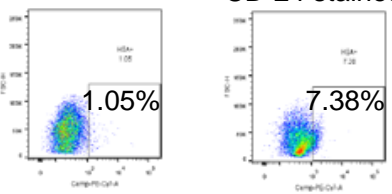

HIV-HSA waste fraction CD-24 stained

HIV-HSA positive fraction CD-24 stained
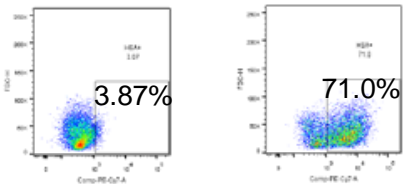

B

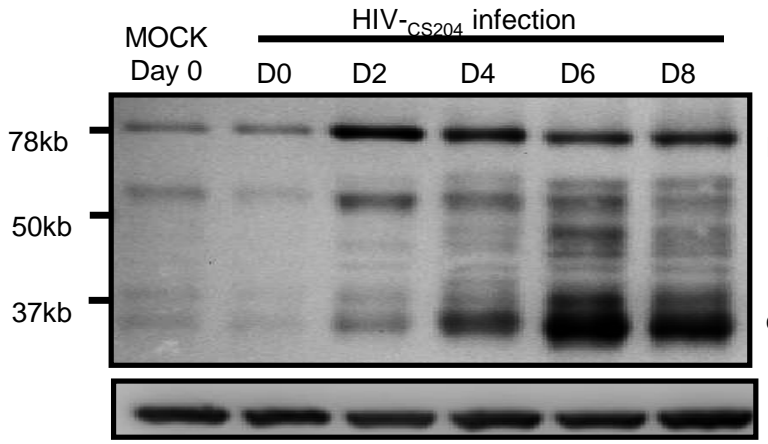

Full length RIP-1

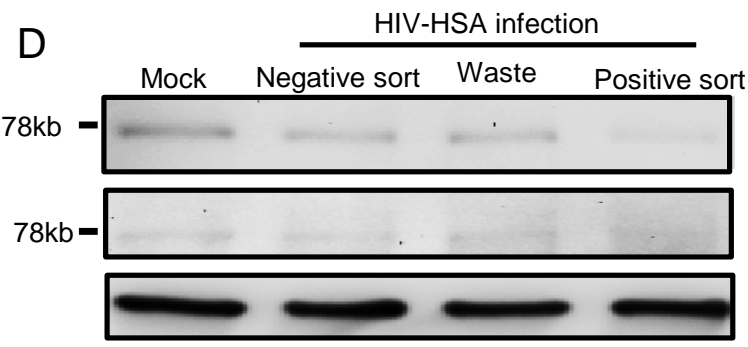

RIPK-1

pRIPK

$\beta$-actin

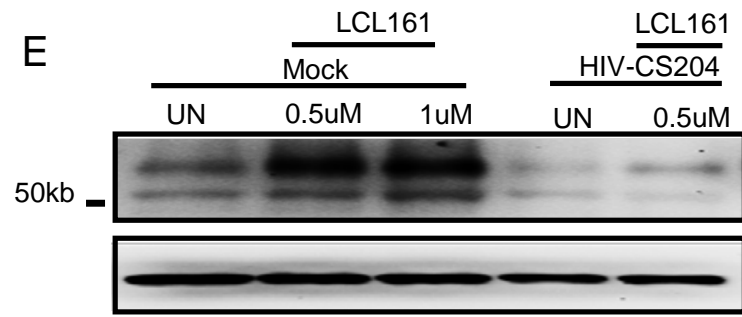

TRAF-1

$\beta$-actin

${ }_{2006}-$

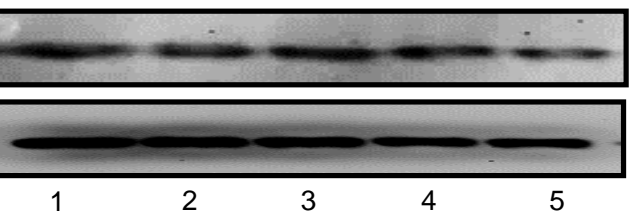

Bax

$\beta$-actin

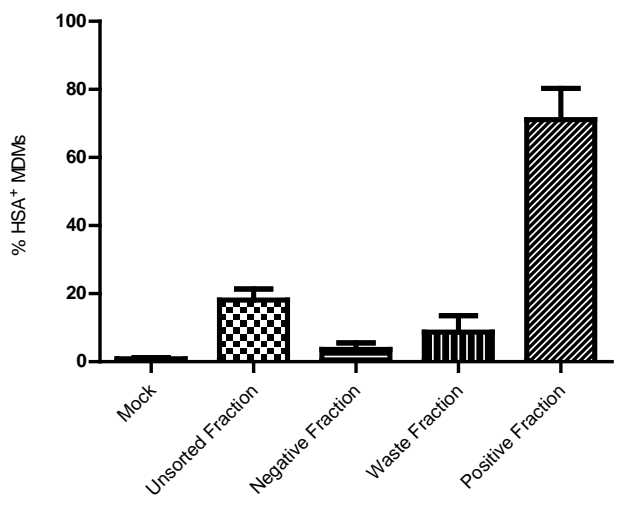

1

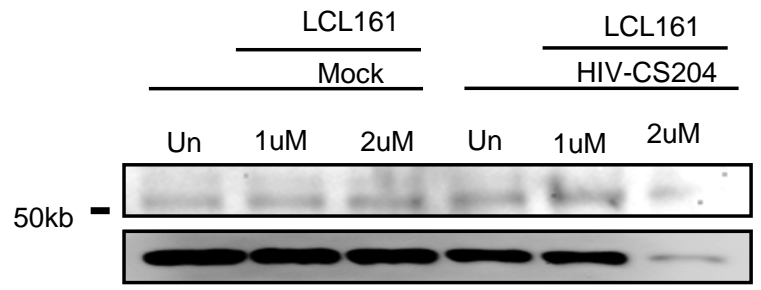

TRAF-2

$\beta$-actin

$20 \mathrm{~kb}$

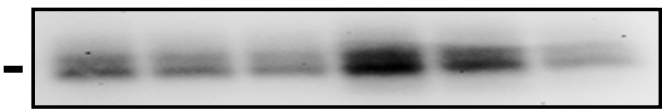

BID

$\beta$-actin 
bioRxiv preprint doi: https://doi org/10.1101/543017; this version posted February 6, 2019. The copyright holder for this preprint (which was not certified by peer review) is the author/funder, who has granted bioRxiv a license to display the preprint in perpetuity. It is made available under aCC-BY 4.0 International license.

A

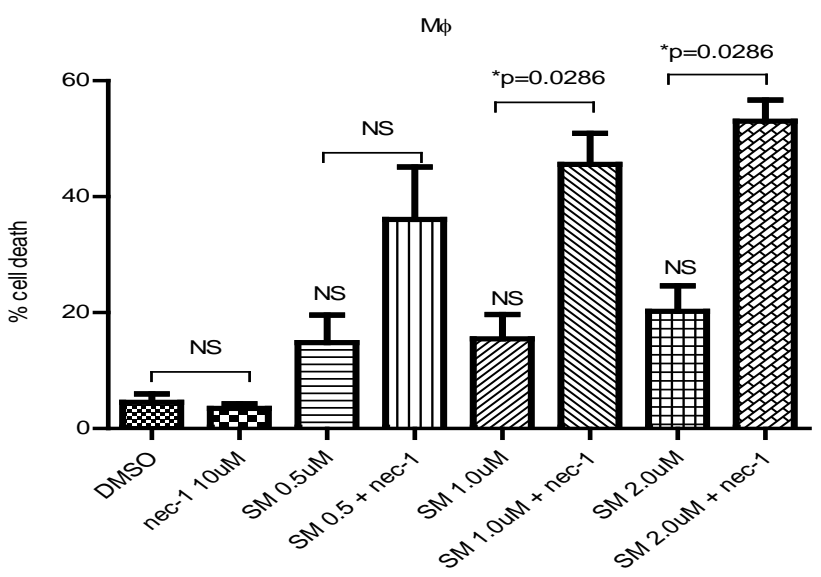

B DMSO

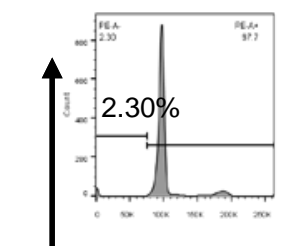

들

SM 1.0 uM

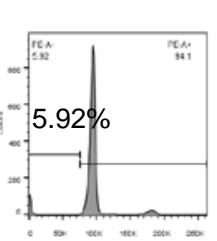

Nec-1

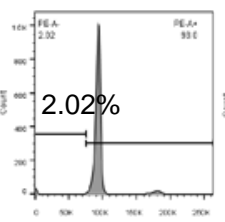

$\mathrm{SM} 1.0 \mathrm{uM}+$ $\mathrm{Nec}-1$

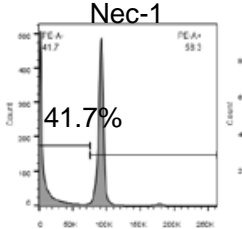

Propidium iodide
SM 0.5 uM

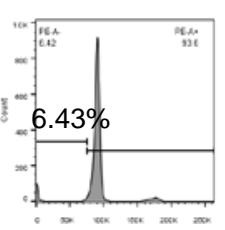

SM 2.0 uM
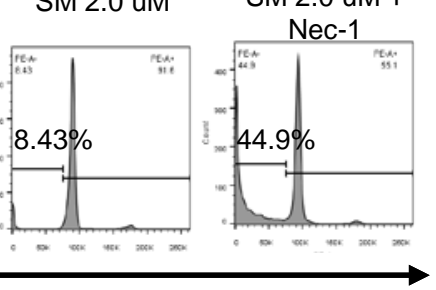

SM 0.5 uM + Nec-1

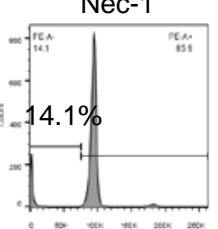

SM $2.0 \mathrm{uM}+$ Nec-1

C

Nec-1
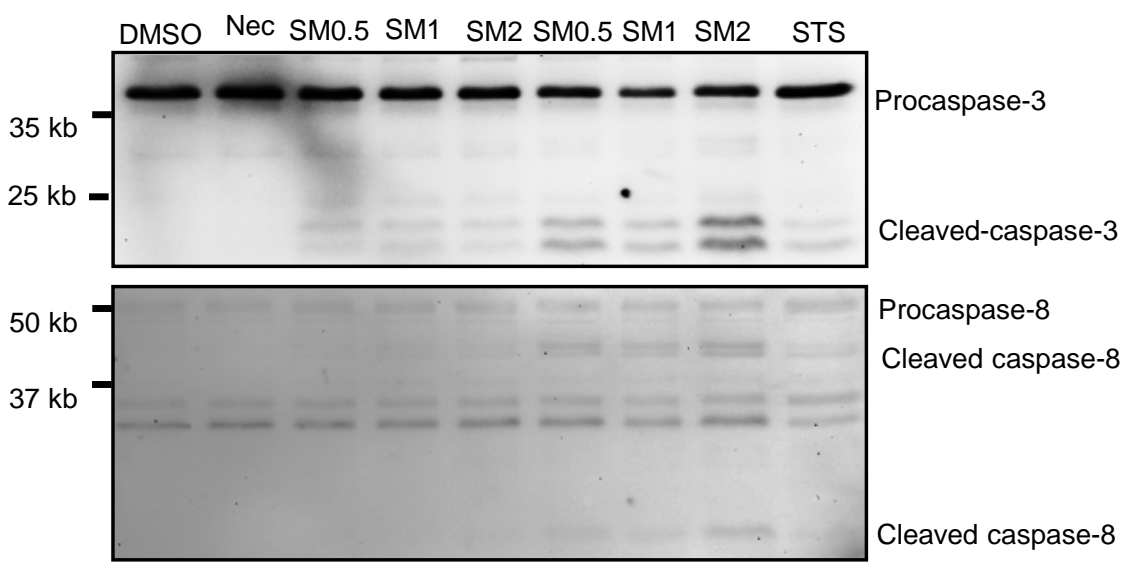

Procaspase-8

Cleaved caspase-8

Cleaved caspase-8

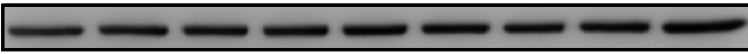

$\beta$-actin

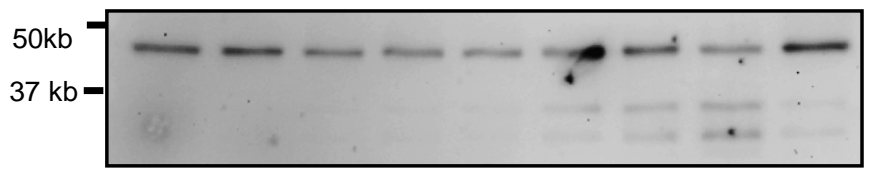

Full-length caspase-9

Cleaved-caspase-9

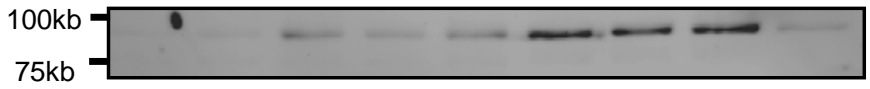

Cleaved PARP

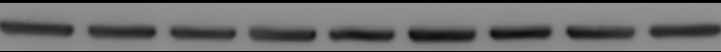

$\beta$-actin 